\title{
Prontuario del Impuesto de Alcabala de Enajenaciones
}

\author{
Por: MANUEL BELAUNDE GUINASSI \\ PRESIDENTE DEL INSTITUTO PERUANO DE \\ DERECHO TRIBUTARIO
}

\section{NOCIONES DEL IMPUESTO:}

Es un impuesto proporcional que grava las transferencias a título oneroso del dominio, acciones o de derechos sobre inmuebles, naves, aportes y adjudicaciones de los mismos.

\section{CLASES:}

1․ - Impuesto general, a las transferencias a título oneroso del dominio de inmuebles, de acciones o de derechos sobre inmuebles $y$ venta de naves nuevas o usadas; aportes de inmuebles a sociedades y adjudicaciones de inmuebles por reducciones de capital o disolución de sociedades.

$2^{\text {o }}$. - Impuestos especiales, aplicables sin perjuicios de la cobranza del impuesto principal, en los siguientes casos:

a).-En la transferencia de concesiones de explotación de petróleo;

b). - En la transferencia de concesiones auríferas;

c). - En la transferencia administrativa de lotes no pagados en las urbanizaciones del Estado;

d). - En la transferencia de concesiones de terrenos ericzos del Estado, para inrigarlos;

e). - En la transferencia de concesiones de aprovechamiento de aguas para la producción de fuerza motriz;

f). - En la transferencia a título onerosó de bienes muebles, acciones - derechos sobre éstos; autos, rentas vitalicias, aportes muebles a sociedades.

\section{LEGISLACION VIGENTE:}

\section{9.-Del Impuesto General:}

A).-Constitución:

Promulgada el 9 de abril de 1933.

De Constitución del Perú, Librería Mejía Baca-Diciembre 1958 ,

Págs. 6, 8, 9, 14, 22, 25, 39. 
Art. 8\%, señala que la ley sólo cuando se trate de servicio público, podrá crear, alterar o suprimir impuestos y exonerar de su pago total o parcial, no habiendo privilegios personales en materia de impuestos.

Art. 17\%, señala que todas las compañías mercantiles nacionales o extranjeras estan sometidas sin restricciones a las leyes de la República y en el caso de reclamaciones ante los tribunales de la República renuncian a las reclamaciones Diplomáticas.

Art. 25\%, señala que ninguna ley tiene fuerza ni efecto retroactivo.

Art. $69^{\circ}$, señala el recurso de habeas corpus, para ejercitarlo cuando se lesionan las garantías individuales y sociales, reconocidas por la Constitución.

Art. $123^{\circ}$ inc. $5^{\circ}$ y $7^{\circ}$, señalando entre las atribuciones del Congreso se encuentran la de imponer contribuciones y suprimir las establecidas sancionar el Presupuesto, aprobar o desaprobar la Cuenta General de la República, aprobar los Presupuestos de los Concejos Departamentales. Dictar las tarifas arancelarias.

Art. 132 , señala la obligatoriedad de la ley desde el día siguiente de su promulgación publicación.

Art. 133\%, señala la acción popular ante el Poder Judicial contra los reglamentos, resoluciones y decretos gubernativos de carácter general que infrinjan la Constitución o las Leyes.

Art. 154, inc. 9\%, establece, que entre las atribuciones del Presidente de la República, se encuentra la de administrar la Hacienda Pública.

Art. 178.-establece, que cada Ministro dirige, de acuerdo con la política general del Ejecutivo, los csuntos que competen a su respectivo Ministerio.

Art. 195\%, señalando la prohibición de la creación y subsistencias de impuestos generales en beneficio de una circunscripción determinada, salvo que el Congreso declare que las obras tengan carácter nacional.

\section{B).-Ley Orgánica del Presupuesto Funcional.}

Promulgada por Ley $N^{\circ} 14816$ del 16 de enero de 1964.

Ley Orgánica del Presupuesto Funcional. Publicación del Ministerio de Hacienda $y$ Comercio, 1964, Págs. 3, 4, 5, 16, 23. 24. 25, 34, 35. 41, 42, 56. 57, 59,60 .

Art. $1^{\circ}$, señala que conforme al art. $9^{9}$ de la Constitución, el Presupuesto General determina anualmente las entradas y gastos de la República y el Congreso en uso de las facultades que le confiere el inciso $5^{\circ}$ del art. $123^{\circ}$ de la Constitución, puede imponer contribuciones y suprimir las establecidas, sancionar el Presupuesto, aprobando o desaprobando la Cuenta General de la República.

Art. 29, establece que el Presupuesto Funcional de la República o Presupuesto General está integrado con los presupuestos de las entidades del Sector Público. La Ley Anual del Presupuesto sanciona el Presupuesto Fun. cional de la Repüblica para cada año financiero, el que coincide con el 
año calendario. La misma Ley Anual establecerá las normas que en cada ejercicio sean necesarias para la programación, formulación, aprobación. ejecución y control del Presupuesto. En ningún caso esas normas modificarán las disposiciones de esta Ley Orgánica.

Art. 27\%, establece que las disposiciones relativas a Ingresos no pueden crear impuestos ni modificar leyes tributarias existentes, sin embargo podrán derogar aquellas cuya recaudación anual mediante el trieno precedente sea inferior a S/. 500,000.00.

Art. 40\%, establece que las normas de aplicación de la Ley Anual de Presupuesto se votarón por artículo. El artículo relativo a los Ingresos se votará por capítulos. Durante la discusión de cada Pliego podrán presentorse proposiciones modificatorias, manteniendo el equilibrio presupuestal.

Art. 44\%, establece que en el año en que conforme a ley se renueven. los poderes Legislativo y Ejecutivo, a solicitud de éste, el Congreso podrá prorrogar el Presupuesto del Gobierno Central hasta por tres dozavos. En tal caso el Presupuesto para el año siguiente se aprobará por los dozavos restontes. Las únicas partidas susceptibles de aplicación retroactivas son los correspondientes al Servicio de la Deuda Pública Externa e Interna consoli. dadas.

Art. 45\%, establece que el ejercicio presupuestario comprende dos períodos: el año financiero que empieza el $1^{\circ}$ de enero y termina el 31 de diciembre en que realizan los ingresos y gastos; y el período complementario de liquidación que comprende del 19 al 31 de enero.

Art. 64\%, establece que la entidades del Sub-Sector Público Independiente, para realizar operaciones de endeudamiento, adquisiciones, licitaciones $u$ otros contratos cuyo valor excede al $5 \%$ de los ingresos anuales, requieren acuerdo unánime de.su directorio u organismo rector. De no obtener tal acuerdo, solicitarón la respectiva autorización por Resolución Suprema del Ministerio con cuyo Despacho mantengan relación funcional o administrativa.

Art. 67\%, establece que la Contraloría General de la República, como organismo autónomo, es el encargado del control presupuestario y patrimonial del Sector Público Nacional, sin perjuicio de la máxima facultada fiscalizadora del Congreso.

Art. 70\%, establece la prohibición de ejercer por su cuenta o intermediarios, las funciones de asesoría, auditoría o contabilidad a los funcionarios o empleados de la Contraloría General de la República.

Art. 77\%, establece que mensualmente la Contraloría General de la República, elevará a las Comisiones de Presupuestos de ambas Cámaras, las cuentas detalladas de la recaudación correspondiente al mes anterior de los ingresos, partida por partida conforme al Presupuesto Funcional.

Art. 109\%, establece que sólo para el Servicio Públics podrá la ley crear, alterar o suprimir impuestos y exonerar de su pago en todo o en parte. No hay privilegios personales en materia de impuestos. Los impuestos serán pagados en efectivo y en la oportunidad señalada por la ley. Se puede cancelar con cheques, bonos, certificados de depósitos con valor cancelatorio conforme a ley. La ley puede variar esta norma.

Art. 115?, los bienes del Sector Público Nacional, sólo podrón ser enajenados en pública subasta por la Dirección de Bienes Nacionales del Mi- 
nisterio de Hacienda, con intervención de la Contraloría General de la República.

\section{C).-Ley Anual del Presupuesto Funcional para 1964.}

Promulgada por Ley $N^{\circ} 14930$ de 29 de febrero. de 1964.

De: El Peruano. 2 de marzo de 1964. Págs. 1,2.

Art. $11 \%$, establece que toda operación que comprometa el crédito del Estado, sea en el país o en el extranjero, en moneda nacional o extranjera, deberá tramitarse y aprobarse obligatoriơmente, sin excepción y previo informe de la Contraloría General de la República, por el Ministerio de Hacienda y Comercio, mediante Decreto Supremo, con el voto aprobatorio del Consejo de Ministros.

Art. 12\%, establece que todos los contratos de compra-venta, de obras o de servicios que se financien total o parcialmente con créditos del Estado, se haran por licitación, bajo pena de nulidad.

Art. 13ㅇ., establece, que todo aval u otra garantía del Estado, será otorgada únicamente por el Ministerio de Hacienda y Comercio, previo estudio. Son nulas las garantías otorgadas en desacuerdo con este artículo.

Art. 14\%, establece, que toda entidad Pública o Privada, como Bancos Estatales, Corporaciones, Compañías Fiscalizadas, informarán de sus obligaciones en moneda extranjera al Ministerio de Hacienda y Comercio.

Art. 16\%. establece que toda adquisición cuyo valor unitario exceda de S. 100,000.00 se hará por licitación pública. Cuando sea superior a los $\mathrm{S} \mid \cdot 10,000.00$ se exigirán cuando menos tres propuestas. Cuando el Estado ejecuta las obras y cuyo valor unitario exceda de $\mathrm{S} \mid . \mathrm{l}^{\prime} 000,000.00$, obligatoriamente será por licitación pública, cuando el monto sea infeior a S. $1^{\prime} 000$, 000.00 y superior a $S \mid 50,000.00$ se realizará cuando menos tres propuestas. Cuando las adquisiciones la efectúen los Ministerios de la Defensa, se obser. varán los requisitos contenidos en esta ley, exceptuándose del de licitación pública en los casos que tengan carácter de "secreto militar", que se someterán a licitación privada, mediante Decreto Supremo, con el voto aprobatorio del Consejo de Ministros.

Art. 17\%, establece que todas las transacciones públicas superiores de S. 5'000,000.00 serán pre-auditadas obligatoriamente por la Contraloría General de la República, y las de monto inferior, se regirán por los principios de pre-auditoría selectivas establecidas por el párrafo $6^{\circ}$ de la ley $\mathrm{N}^{\circ} 14816$.

Art. $30^{\circ}$, establece que la interpretación del término de la prescripción de los impuestos a la renta que establece el art. $96^{\circ}$ de la ley $\mathrm{N}^{\circ} 7904, \mathrm{co}-$ mienza a correr desde el día siguiente al vencimiento del plazo fijado para la presentación de la respectiva declaración jurada, a excepción del im. puesto $\alpha$ la renta del capital movible que empieza desde la cancelación de intereses.

Art. $32^{\circ}$, establece que las devoluciones por pago indebido de impuestos y derechos, serán realizados con cargo a la misma partida de Ingresos; mediante Resoluciones del Superintendente de Contribuciones o de Aduana, hasta por la suma de S| $300,000.00$ y mediante Resolución Ministerial 
del Ministerio de Hacienda, cuando supere dicha suma, publicándose mensualmente en el Diario "El Peruano" una relación de las devoluciones.

Loy No 15270 de Presupuesto Funcional de la República 1965.

\title{
Promulgada el 31 de Diciembre de 1954
}

\author{
De: Código Civil 1936. Segunda Edición Oficial, Págs. 9, 11, 133, 134. \\ $135,139,140,145,146,147,148,149,150,151,152,153,157$. \\ 175, 176, 181, 209, 213, 214, 215, 216, 218, 219, 221, 222, 223, 234.
}

\section{D).-Código Civil}

Promulgadó por Decreto Supremo de 30 de agosto de 1936, en uso de la autorización contenida en la ley № 8305

\section{Título Preliminar:}

I. -establece que la ley se deroga por otra ley.

XXI. -establece que los jueces no pueden dejar de aplicar las leyes.

XXII.-establece que cuando hay incompatibilidad entre disposición constitucional y una legal se prefiera la primera.

XXIII. - establece que los jueces no pueden dejar de administrar jus. ticia por deficiencia de la ley, en tal caso aplicarún los principios generales del derecho.

\section{DE LOS BIENES}

Art. 822\%, enumera los inmuebles, que son:

10.--Las tierras, minas y aguas públicas;

2\%.-Los predios;

$3^{\circ}$ - Las minas concedidas a los particulares;

4?.-Las naves y aeronaves;

5 . - Los ferrocarriles y sus vías;

$6^{\circ}$.- - Los muelles y los diques;

$7^{\circ}$.-Las concesiones y autorizaciones para exploter servicios públicos;

$8^{\circ}$. - Los derechos sobre inmuebles, inscribibles en el registro de la propiedad.

Art. $813^{\circ}$, establece, que es parte integrante de un bien lo que no puede ser separado sin destruir, deteriorar o alterar el mismo bien.

Ari. 814 ${ }^{\circ}$, establece, que no pierden el carácter de parte integrante de un edificio los materiales que se han separado mientras se efectúan reparaciones.

Art. 815\%, establece, que es accesorio de un predio todo lo que está aplicado permanentemente a su fin económico y se encuentra en una relación que responda a ese fin.

La separación temporal de los bienes no les hace perder su calidad. 
Art. 816\%. establece, que los árboles plantados, las semillas sembradas y los frutos mientras no están percibidos tienen el carácter de accesorios.

Art. 817\%, establece que las partes integrantes, y los accesorios de un bien siguen la condición de éste, salvo en los casos que la ley o el contrato lo diferencien.

\section{BIENES DEL ESTADO Y DE PARTICULARES}

Art. 821\%, establece, que son bienes de propiedad privada los de los particulares que tienen títulos reconocidos por la ley.

Art. 822\%, establece que son bienes del Estado los siguientes:

1‥-Los bienes de uso público;

2 . - El mar territorial y sus playas y la zona anexa que señala la ley de la materia;

$3^{\circ}$.-Los bienes que le corresponden por título legal, no comprendidos en los otros incisos de este artículo:

$4^{\circ}$.-Las tierras públicas entendiéndose por tales la que no han tenido dueño y las que han sido abandonadas por el dueño que tuvieron; las minas y los bosques y demás fuentes naturales de riquezo antes de su concesión; los ríos y demás aguas comientes y los lagos, así como sus respectivos cauces y álveos;

$5^{\circ}$.-Los monumentos históricos y los objetus arqueológices que están regidos por su ley especial:

6\%.-Las rentas nacionales.

Art. $823^{\circ}$, establece que los bienes de uso público son inalienables $\theta$ imprescriptibles.

\section{DE LA PROPIEDAD INMUEBLE}

Art. 854\%, establece que la propiedad del predio se extiencie al suelo y subsuelo, comprendido dentro de los planos verticales del perímetro superficial. Esta regla comprende la propiedad de lo que se encuentra bajo el suelo, a excepción de las minas y las aguas que están regidas por leyes especicles.

Art. 855\%, establece que los pisos de un edificio pueden peitenecer a diferentes propietarios y si no existen pactos se observarón las siguientes reglas

1.--Las paredes maestras y las medianeras, los techos, las puertas de entrada y demás abras serán costeadas en proporción al valor de cada piso:

$2^{\circ}$ - - Al propietario de cada piso le corresponde costear el suelo de su piso $y$ al último, el techo del suyo;

$3^{\circ}$.-Las escaleras se costearán por los dueños de los pisos a que sirven, según el valor de cada piso;

4\%.-El alcantarillado y las aceras y pavimentación de la calle se pagará a prorrafa entre todos. 


\section{DEL CONDOMINIO}

Art. 895\%, establece, que en la propiedad común o indivisa cada propietario puede ejercer los derechos inherentes a la propiedad, compatibles con la indivisión del bien.

Art. $897^{\circ}$, establece que las mejoras necesarias y útiles pertenecen $\alpha$ todos los copartícipes con la obligación de responder proporcionalmente por los gastos.

Art. 898. establece que la prescripción ganada por un condómino aprovecha a todos.

Art. 899\%, establece que los copartícipes están obligados a reembolsarse de los provechos obtenidos del bien.

Art. $900^{\circ}$, establece que todos los partícipes están obligados a concumir en proporción a su parte a los gastos de conservación y al pago de impuestos y gravámenes.

Art. $901 \%$, establece que si los copartícipes individualmente practican sobre todo el bien o sobre parte material de él un acto que importa el ejercicio de la propiedad exclusiva, dicho acto será válido si adjudica el bien - la parte a quien practicó el acto.

Art. 902 ${ }^{\circ}$, establece que la acción de partición es imprescriptible, y ninguno de los condóminos puede adquirir los bienes comunes por prescripción.

Ãrt. $903^{\circ}$, establece los copropietarios están obligados a hacer partición cuando uno de ellos 0 el acreedor de cualquiera lo pida, salvo el caso de indivisión forzosa o de pacto o ley que fije plazo para la partición.

Art. $904^{\circ}$, establece que cuando el condominio recae sobre un patrimonio, la partición comprenderá todos los bienes que lo forman, salvo que los interesados estén de acuerdo con hacerla parciclmente.

Art. $965^{\circ}$, establece que el plazo para suspender la partición no excederá de cuatro años, y cualquier otro se reducirá a éste; pudiendo renovarse indefinidamente.

Art. 966\%, establece que para que produzca efecto contra terceros, el pacto de indivisión debe inscribirse en el registro de la propiedad inmueble. Esta regla es aplicable a la administración del bien.

Art. 907\%, establece que si la indivisión se ha pactado sin tiempo fijo, terminará cuando lo pida cualquiera de copartícipes con anticipación de seis meses. Tratándose de predio rústico se esperará la terminación del año rural que hubiere comenzado.

Art. 908\%, establece que si el bien indiviso es un fundo, una nave 0 un negocio industrial, cualquiera de los copropietarios puede emprender los trabajos de explotación normal, si no se ha establecido la administración común y mientras ésta no ha sido solicitada.

Art. 909\%, establece que el copartícipe que emprende la explotación, asume la situación de administrador y sus actos no deberón exceder de los que corresponden ordincriamente a la administración de negocio. La retribución por la administración será con parte de las utilidades, en caso de desacuerdo la fijará el Juez.

Axt. $910^{\circ}$, establece que las paredes, cercos o zanjas situados entre dos predios, se premunen comunes, salvo prueba en contrario. 
Art. 911, establece que la presunción del art: $910^{\circ}$ se extiende hasta la altura del edificio menos elevado.

Art. 912\%, establece que el exceso de la. pared se reputa que pertenece al dueño del edificio más elevado, salvo prueba en contrario.

Art. 913\%, establece que los colindantes deben contribuir a prorrata para la conservación, reparación o reconstrucción de la pared medianera, salvo que renuncien a la medianería o no hagan uso de ella.

Art. 914, establece que todo colindante puede servirse de la pared medianera, sin deteriorarla, colocando tirantes, vigas, pero no puede abrix ventanas ni claraboyas.

Art. 915. establece que si la pared que separa dos predios es levantado en terreno de uno de ellos, el vecino puede obtener la medianería pagando la mitad del valor de la obra y del suelo ocupado. En tal caso puede pedir la supresión de todo lo que sea incompatible con el derecho que le dá la medianería.

Art. 916\%, establece, que cualquier colindante puede levantar la pared medianera, corriendo con los gastos de la reparación y cualquiera otros que exigiera la mayor altura. tición por convenio.

Art. 917\%, establece que los interesados capaces pueden hacer par-

Art. $918^{\circ}$, establece que si alguno de los interesados es ausente o incapaz, la partición debe ser judicial. Puede hacerse partición extrajudicial o por medio de árbitros, pero ésta será aprobada por el Juez, previa tasación, con audiencia del consejo de familia en su caso, y dictamen de dos letrados y del ministerio fiscal.

Art. 919\%, establece que si los bienes son materialmente patibles o no se prestan a cómoda división, se venderán en pública subasta.

Art. 920\%, establece que cualquiera de los interesados tiene ol derecho de tanteo o preferencia para evitar la venta de los bienes y adquirir la propiedad de ellos, entregando en dinero el precio de la tasación, en las partes que correspondan a los demás condóminos.

Art. 921\%. establece que los condóminos están recíprocamente obligados a la evicción y saneamiento, en proporción a la parte de cada uno.

Art. 922 $2^{\circ}$ establece que por la partición permutan los condóminos, cediendo cada uno el derecho que tienen sobre los bienes que no se le adjudican a cambio del derecho que le ceden en los que se le adjudican.

Art. 923\%, establece que las reglas que rigen el condominio en cuanto sean aplicables, rigen para la comunidad de derechos.

\section{DEL USUFRUCTO}

Art. 924, establece que el usufructo importa el pleno disfrute del bien, salvo que estén excluidos determinados provechos o utilidades. de bienes.

Art. 925\%, establece que el usufructo puede versar sobre toda especie

Art. 927\%, establece que pertenecen al usufructuario los frutos naturales y los de la industria agrícola pendientes al comenzar el usufructo; y al propietario, los pendientes a su término. 
Axt. 929\%, establece, que el usufructuario debe explotar el bien en la forma normal $y$ acostumbrada.

Irt. 930\%, establece que si el usufructo es de especies que se consuman, el usufructuario se convierte en propietario, con cargo a devolver otra en igual cantidad $y$ calidad o de porgar el valor estimado al tiempo de constituir el usufructo.

Art. 931\%, establece que cuando el usufructo recae sobre animales de labor, material de explotación industrial u otros análogos, está autorizado para devolver otros de la misma clase recibidos.

Art. 932:, establece que el usufructuario puede explotar las sustancias minerales si son las que pertenecen al dueño del suelo.

Art. 934\%, establece que el usufructuario está obligado a efectuar las reparaciones ordinarias, $Y$ si por su omisión se necesitan obras extraordinarias debe hacer éstas.

Art. 935\%, establece que el usufructuario debe pagar las contribuciones, las rentas vitalicias y las pensiones de alimentos que graven los bienes.

Art. 936?, establece que si el usufructucrio paga la deuda hipotecaria o el interés que ésta devenga, se sustituye en el crédito pagado.

Art. 937\%, establece, que el usufructuario debe hacer inventario y tasación al entrar en posesión del usufructuo, tratándose de bienes muebles. El inventario y tasación será judicial tratándose de usufructuo legal o del testamentario.

Art. 938\%, establece, que el propietorio puede oponerse a todo acto del usufructuario que importe una infracción del artículo $929^{\circ}$ y pedir al juez que regule el uso o la explotación.

Art. 939\%, establece, que el usufructuario se encuentra obligado $\alpha$ otorgar garantía señalada en el título constitutivos de sus derechos, o la que ordenare el juez, cuando peligren los derechos del propietario.

Art. 940\%, establece, la prohibición de las modificcaciones sustanciales del bien o de su uso. Pero puede el usufructuario cambiar las plantaciones del fundo.

Frt. 943, establece, que el usufructo termina con la muerte del usufructuario, cuando no se ha fijado plazo para su término.

Art. $944^{\circ}$, establece, cuando el usufructo se pacta su término $\alpha$ favor de una persona, hasta llegar a cierta edad, termina con la muerte de ella.

Firt. 945\%, establece, que el usufructo establecido en favor de varias personas, se extingue a la muerte de la última.

Art. $946^{\circ}$, establece, que en el caso de expropiación, el valor de la indemnización reemplazará al bien materia del usufructo.

Art. 947, establece, que en el usufructo convencional $y$ en el testamentario, la indemnización se distribuirá, en la proporción que matemáticamente corresponda entre el propietario y el usufructuario, quedando extinguido el usufructo.

Firt. $948^{\circ}$, establece que por prescripción se adquiere $y$ se pierde el usufructo, si se posee o deja de poseer por el tiempo y con las condiciones establecidas para la propiedad.

Rrt. 949\%, establece que cuando un edificio se destruye, sin culpa del propietario, éste no está obligado a reconstruirlo, si lo hace, cesa el usufructo. 
Art. 950. establece, el límite de 30 años pac el límite del usufructo a forvor del Estado, o de una Corporación, o de un pueblo o de una persona jurídica, cualquier tiempo mayor que se fije, se reduce a éste. Si la persona jurídica llamada al goce se disuelve antes de terminar el plazo previsto, el usufructo se disuelve.

\section{DEL USO.-}

Art. 951\%-establece que el derecho de usar o de servirse de un bien no consumible se rige por las disposiciones del usufructo, en cuanto le sean. aplicables.

Art. 952.--establece, que cuando el derecho de uso recae sobre una casa o parte de ella pora servir como de morada, se estima constituído el derecho de habitación.

Art. 953․-establece, que los derechos de uso y habitación pasan a la familia del usuario, salvo pacto en contrario.

Art. 954․--establece, que los derechos de uso y habitación no pueden ser materia de ningún acto jurídico, excepto la consolidación.

Art. 957\%.-establece, que el usufructo sobre las minas de los hijos menores, comprende el derecho a los minerales extraídos, pero el padre restituirá la mitad de su valor líquido.

Art. 953.-establece, que por actos entre vivos puede constituirse usufructo sobre tierras edificables teniendo el usufructuario el derecho de propiedad sobre el edificio que levante.

Fryt. $959^{\circ}$.--establece que el derecho del art. 958, podrá constituirse como máximo por 99 años, pasados los cuales el edificio será de propiedad del dueño del suelo.

\section{DE LAS SERVIDUMBPES.-}

Firt. $960^{\circ}$.-_establece que la ley o el propietario de un predio puede imponeile gravámenes en beneficio de otro, que dén derecho al dueño del predio cominanie para practicar ciertos actos de uso del predio sirviente o para impedir al dueño de éste el ejercicio de alguno de sus derechos.

Art. $961 \%$.- establece, que el derecho de servidumbre es inseparable del predio dominante y se transfiere con él, el gravámen subsiste en el predio sirviente, cualquiera que sea el dueño.

Art. $962^{\circ}$.- esiablece, que la servidumbre se debe entera a cada uno de los dueños del predio dominante y por cada uno de los del sirviente.

Art. $963^{\circ}$.- - establece, que si el predio dominante se fracciona, la servidumbre subsiste $\alpha$ favor de los porcionistas que la necesiten, sin aumentarla.

Art. 964\%.-establece que las servidumbres son perpetuas, salvo disposiciones de la ley o pactos que fijen plazos.

Art. $965^{\circ}$.- -establece, que el predio sirviente no podrá menoscabar el uso de la servidumbre. Si por razón del lugar o modo la servidumbre resulta incómoda podrá variarla si no perjudica su uso.

Art. $966^{\circ}$.- -establece, que sólo por prescripción se pueden adquirir las servidumbres aparentes y contínuas, con las condiciones fijadas para adquirir inmuebles. 
Art. 967\%--establece, que el usufructuario puede constituir servidumbre por el tiempo del usufructo.

El propietario puede establecer servidumbres sobre la finca gravada con usufructo, siempre que no perjudique al usufructuario.

Art. $968^{\circ}$.-establece, que el condómino puede adquirir servidumbre en beneficio del predio común, aunque lo ignoren los demás partícipes.

Art. 969. -establece, que en el caso de destrucción total del edificio de cualquiera de los dos predios urbanos, no reviven las servidumbres por la reedificación salvo las referentes al suelo.

Art. 970\%.-establece, que la servidumbre se conserva por el uso de una persona extraña, si lo hace en consideración al predio dominante.

Art. 971:--establece que la extensión y demás condiciones de las servidumbres se rigen por el instrumento de su constitución y a falta de ésta, por las disposiciones del $\mathrm{CC}$ en el título respectivo.

Art. $972^{\circ}$.-establece, que el costo de las obras que ejecute el dueño del predio dominante son por cuenta de éste, reclizando las obras de tal manera que no causen incomodidad al dueño del predio sirviente.

Art. $973^{\circ}$.- establece, que el modo de prestar servidumbre percibe en la misma forma que la servidumbre (art. 964).

Art. 974\%.-establece, que la servidumbre legal de paso se establece en beneficio de los predios que no tengan salida a los caminos públicos.

Esta servidumbre cesa cuando el propietario adquiere un inmueble por donde tenga salida o cuando se abre un camino que dé acceso inmerdiato a él.

Art. 975.--establece, que la implantación de la servidumbre legal de paso requiere previo pago del terreno ocupado y los perjuicios que resultaren.

Art. 976\%--establece que la amplitud del camino se fijará según las circunstancias.

Art. 977\%. - establece, que el propietario de dos predios, puede gravar con servidumbre el uno en beneficio del otro.

Art. 978\%.-establece que las servidumbres de cable carril y paso de energía eléctrica, están sujetas a su ley especial.

Art. 979.--establece, que el dueño del predio ajeno debe otorgar permiso para pasar por su propiedad las materias, colocar andamios para re. parar el edificio previo pago de una indemnización por el perjuicio.

Art. $980^{\circ}$.- establece que él adquiere un predio enclavado en otro del enajenante, adquiere derecho al paso sin pagar indemnización.

\section{ANTICRESIS.-}

Art. $1004^{\circ}$--establece, que se entiende por anticresis la entrega de un inmueble en garantía de un préstamo en dinero, concediendo al acreedor el derecho de explotarlo y percibir los frutos.

Art. 1005\%.-esiablece, que la anticresis, se otorgará mediante escritura pública, expresando la renta del inmueble y el interés que se pacte.

Art. 1006\%.--establece, que la renta del inmueble se aplicará al pago del capital, si no se pactó intereses, y habiendo intereses, al pago de éstos primero, y lo que sobre al pago del capital. 
Art. 1007\%,-establece, que las obligaciones del acreedor son las mismas del arrendatorio, excepto la de la entrega de la renta.

Art. 1008\%.- - stablece, la prohibición al acreedor de retener el inmueble por otra deuda, si no se le otorgó ese derecho.

Art. 1009\%--establece, que son aplicables a la anticresis las reglas establecidas pana la prenda en lo que no se opongan a las consignadas en los arts. 1004 al 1008.

\section{DE LA COMPRA-VENTA.-}

Art. 1383 - - establece, que por la compra-venta el vendedor se obliga a transferir la propiedad de una cosa, y el comprador a pagar el precio en dinero.

Art. 1387\%.-establece, que es válida la venta aunque no se hubiese convenido el precio, si en el contrato se designa una tercera persona que lo determine; más si el nombrado. ni puede ni quiere hacerlo, caduca la venta.

Art. $1328^{\circ}$.- - establece, que se considera fijado el precio cuando se conviene que sea el que la cosa tuviera en lugar y tiempo determinado. Cuando las partes al fijar el precio de la cosa se refieren al corriente en cierto lugar $Y$ tiempo, $y$ ese tiempo es tal, que durante él pudiera variar el precio, se entenderá que convinieron en el medio proporcional entre el más alto y el más bajo, salvo pacto en contrario.

Art. 13899.--establece, que se entiende fijado el precio si las partes se refieren al que resultare de la tasación íntegra o con cierta rebaja convenida, sometiéndose ademá a la decisión judicial en caso de disconformidad en la tasación. Se entenderá igualmente fijado el precio, si se conviene que sea el más alto que se obtenga por la cosa sometida a subasta pública.

Art. 1390. - establece, que si cuando se hizo la venta, la coosa vendida había parecido no hay venta. Y si sólo había perecido una parte, el comprador tiene derecho a retractarse del contrato o a una rebaja por el menoscabo, proporcional al precio que se fijo por el todo.

Art. 1391. - establece, que los contratantes pagarán por mitad los impuestos y gastos del contrato, salvo pacto en contrario.

Art. 1410.-establece, que el comprador debe pagar el precio en el día y lugar estipulado.

Art. 1411.-establece, que cuando no se estipularon lugar y día se pagará el precio en el día y lugar en que la cosa debe ser entregada.

\section{DE LA PROMESA DE VENTA-}

Art. 1392.--establece, que el convenio por el cual una persona promete vender 0 compror $\alpha$ otra, alguna cosa por un precio y en un plazo determinado, produce los efectos de la compra-venta, desde que el coestipulante declare en el plazo fijado, su voluntad de comprar o vender.

Art. 1393.- -establece, que en la promesa de venta, se designará el plazo. Este plazo no purede pasar de dos años, para los inmuebles o derechos sobre inmuebles, si no hay plazo convencional, se entiende fijado por dos coños. 
DE LA VENTA DE COSAS FUTURAS.-

Art. 1395.-establece que puede venderse las cosas futuras, antes de cue existon en especie y también una esperanza incierta. Puede igualmente venderse la cosa litigiosa, si se instruye al comprador del pleito sobre ella.

\section{DE LA ANULABILIDAD EN LA COMPRA_-VENTA}

Art. 1394.-establece, que la venta de cosa ajena es anulable a solicitud del comprador, salvo que éste hubiese sabido que la cosa no pertenecía al vendedor. Puede además demandar al vendedor la restitución del precio y pago de los daños y perjuicios.

\section{DE LA NULIDAD EN LA COMPRA-VENTA.-}

Art. 1396.-establece, que no puede venderse la herencia de una persona que vive, aunque ésta preste su consentimiento. de otro:

Art. 1397.-establece, que no pueden comprar por sí, ni por medio

1.-El administrador público, los bienes que estén a su cargo;

2.-El mandatario, sin permiso expreso del mandante, los que por el mandato tiene $\alpha$ su cuidado:

3. - El albacea, los bienes que administra;

4.-El juez, el abogado, el escribano, el procurador y los peritos, los bienes que se vendan en el juicio en que han intervenido.

5.-El Presidente de la República y los ministros de Estado, los bienes nacionales;

6. -Los prefectos, subprefectos y gobemadores, los bienes nacionales, situados en el territorio de su jurisdicción.

7. - Las demás personas a quienes la ley lo prohiba.

No regirá la prohibición de los incisos $1^{\circ}, 2^{\circ}, 3^{\circ}$, y $4^{\circ}$ respecto del abogado, cuando se trate de derechos entre comuneros, 0 de adjudicación en pago.

Art. 1398. establece, que la nulidad establecida en el art. 1397، sólo puede pedirla el dueño de la cosa vendida.

\section{DE LA RESCISION EN LA COMPRA-VENTA.-}

Art. 1354.-establece, que por vicios ocultos de la cosa el adquiriente tiene derecho a pedir, a su elección o que se rescinda el contrato, o que se le devuelva del precio lo que la cosa vale menos.

Art. 1401.-establece, que si por culpa del vendedor no se realiza la entrega de la cosa en el tiempo convenido o legal, el comprador, a su elección, tiene el derecho de pedir, o la rescisión del contrato o la entrega de la cosa.

Art. 1413.-establece, que en el caso de rescisión por falta de pago de precio, o de otorgamiento de garantía estipulada, será condenado el comprador que recibió la cosa, a restituir frutos, o en lugar de éstos al pago 
de intereses del precio; y además a la satisfacción de los impuestos y gastos del contrato y reparación de perjuicios.

Firt. 1414.-establece, que cuando se ha pagado parte del precio, y en contrato no se estipuló plazo para el pago de la otra parte, se declarará la rescisión que pida el vendedor, si el comprador no paga el resto del precio dentro de ocho días después de notificada la demanda. Rescindido el contraio, el vendedor devolverá la parte del precio pagado, deducidos los impuestos y gastos del contrato.

Art. 1415.-establece, que si se rescinde el contrato de venta a carisa de no haberse otorgado en el plazo convenido la garantía debida por el resto del precio, el vendedor devolverá la parte del precio pagado, deducidos los impuestos y gastos del contrato.

Art. 1421.-establece, que si el exceso o falta en la extensión de la cosa venơida es mayor que de un décimo, queda a elección del comprador, o pagar lo que hubiese de más y cobrar en su caso lo que resulte de menos, o rescindir el contrato.

Art. 1424.-establece, que en la venta de inmuebles en que se hubiese estipulado el pago del precio por partes, en diferentes plazos, puede el vendedor pedir la rescisión si el comprador dejase de efectuor dos pagos.

Art. 1425. - establece, que no tiene el vendedor derecho a pedir la rescisión sino sólo a cobrar el saldo, los intereses y los gastos, si se le ha pagado ya más de la mitad del precio, salvo pacto en contrario.

Art. 1427.-esiablece, que el comprador de inmuebles, o de derechos y acciones sobre ellos, aunque se le haya entregado la cosa, puede retener el precio o la parte que debiere, mientras el vendedor le demore el otorgamiento de la escritura pública. En este caso, no debe el comprador intereses de la cantidad retenida.

Art. 1428. - establece, que puede rescindir la venta de inmuebles por haberse convenido en el contrato que si dentro del término fijo hubiese quien dé más por la cosa, la devolverá al comprador. Este término no puede exceder de un año, aunque se estipule otro mayor.

Art. 1433.--establece, que todo inmueble, derecho, acción o renta del Estado que por leyes especiales no se venda o adjudique de otra manera, se venderá en subasta pública, bajo pena de nulidad. A este remate procede el avalúo que harán los peritós nombrados por la junta de Almonedas y la publicación de avisos conforme al C.P.C.

\section{DEL RETRACTO.-}

Art. 1445.-establece, que el derecho de retracto no procede sino en los casos de venta o de adjudicación en pago.

Art. 1446.-establece, que el derecho a retracto tiene una duración de treinta días, contados a partir de la notificación judicial a la persona que gaza de este derecho o del aviso inserto en el periódico del lugar de la situación de la cosa.

Art. 1448.--establece, que por el derecho de retracto no puede cederse ni pasa a los herederos.

Frt. 1450.-establece, que tienen derecho a retracto:

1.-El condómino, en la venta de las porciones indivisás o de la $\cos \alpha$. 
$2^{\circ}$.-El socio, en la venta de las cosas de la sociedad.

$3^{\circ}$.-El dueño del dominio directo, en la venta del dominio útil, Y al contrario.

4․-El propietario, en la venta del usufructo, y al contrario;

$5^{\circ}$. - El propietario de la tierra colindante, cuando se trate de la venta de una finca rústica cuya extensión no exceda de tres hectáreas o cuando aquella y ésta reunidas no excedan de diez;

6\%. - El demandado, en caso de cesión por el demandante, de la cosa o derecho que se está discutiendo judicialmente;

7 . - Los propietarios de los diferentes pisos de un edificio, en la venta de ellos a un extraño;

8.- - Los propietarios de predios urbanos, que cunque divididos materialmente en partes, no pueden ejercitar sus derechos de propietarios, sin someter las demás partes de la cosa a servidumbres o servicios que disminuyan su valor.

Art. $1451^{\circ}$-establece, que si hay diversidad en títulos de dos o más personas, con derecho a retraer, el orden de preferencia será indicado conforme el orden del artículo 1450 .

Art. $1452^{\circ}$.-establece, que no se aplicará el inciso $6^{\circ}$ del art. 1450 , en los casos $\alpha$ ) que se hubiere hecho cesión a un acreedor en pago de los que se le debía y b) si se hizo al poseedor del predio sujeto al derecho litigioso.

Art. 1453?.-Establece, que si dos o más colindantes usan, del derecho de retracto, será preferido el que de ellos sea el dueño de la tierra de menor extensión, y si las dos tuvieran igual, el que primero lo solicitó.

Art. $1454^{\circ}$.-establece, que si varios socios o condóminos intentan la acción de retracto, todos serán admitidos. y adquirirán la parte retraída en proporción de su participación en la cosa común o de su acción en sociedad.

Art. 1455.-establece, que cuando se haya realizado dos o más ventas antes de que termine el plazo para solicitar el retracto, éste se refiere a la primera venta y se verifica por el precio y las condiciones de ella. El retrayente no pagará otros gastos, sino los de la primera venta, aunque dirija su acción contra el último adquiriente que tenga la posesión de la cosa.

\section{DE LA CESION DE CREDITOS.-}

Irt. 1456\%-establece, que el acreedor puede ceder su crédito, si a ello no se opone la naturaleza de la obligación, la ley o la convención con el deudor.

Art. 1457\%.-establece, que el cesionario no adquiere la acción contra el deudor cedido por los derechos que se le hubiere trasferido, sino desde que éste acepta la traslación, o desde que le notifica judicialmente.

Art. 1458,-establece, que el que cede un crédito $u$ otro derecho, debe sanear su existencia al tiempo de la enajenación.

\section{DE LA NULIDAD DE LOS ACTOS JURIDICOS.-}

Art. 1125․-establece, que el acto jurídico es anulable: 
19.-Por incapacidad relativa del agente:

$2{ }^{\circ}$.-Por vicio resultante de error, dolo, violencia, intimidación, simulación o fraude.

\section{DE LAS OBLIGACIONES DE NO HACER.-}

Art. 1188\%.-establece, que la obligación queda extinguida, cuando sin la culpa del deudor, la obligación de no hacer y la omisión del hecho resultare imposible.

\section{DE LA PRESCRIPCION EXTINTIVA.-}

Art. 1167.-establece, que la interrupción de la prescripción la puede pedir el titular del derecho, o por intermedio de un tercero.

Art. 1168\%.--establece, que prescriben:

toria:

$1^{\circ}$. - A los veinte años, la acción real y la que nace de una ejecu-

$2^{\circ}$. - A los quince años, la acción personal;

$3^{\circ}$. - A los dos años, de la fecha de su celebración, la acción para anular los actos o contratos que hubo error, dolo, fraude, coacción o incapacidad relativa del agente; en caso de coacción, este plazo se cuenta $\alpha$ partir del día en que aquella cese, y en el de la incapacidad relativa desde aquel en que el agente adquirió la plena capacidad;

$4^{\circ}$. - A los tres años, la acción de los abogados, médicos, cirujanos, dentistas, maestros, boticarios, hoteleros, peritos, profesores, ingenieros, agnimensores, arquitectos, procuradores, artesanos, mayordomos, dependientes de casa o heredad, jornaleros y sirvientes domésticos, para reclamar su salarios u honorarios. Este plazo se cuenta a partir del día en que cesaron los servicios.

$5^{\circ}$. - A los tres años, la que proviene de pensiones alimenticias y la de suministro de víveres para el consumo.

$6^{\circ}$. - A los dos años, a partir del día en que se causó el daño, la acción para exigir su reparación.

7ơ. - A los tres años, a partir del día en que cesó la incapacidad, las acciones de los menores o incapacidad contra sus padres:

$8^{9}$. - A los quince años, la acción de daños y perjuicios derivados para las partes de la violación de un acto simulado. Este plazo se cuenta a partir del día de la violación.

Art. 1169\%.-establece, que la acción de nulidad de un acto o contrato prescribe a los treinta años.

\section{DE LA SEPARACION DE BLENES DURANTE EL MATRIMONIO}

Art. $241 \%$-establece, que a pedido de la mujer el juez puede decretar la separación de bienes en los siguientes casos:

1‥-cuando el marido no cumple con la obligación de suministrar a la mujer y en general a la familia todo lo necesario para la vida, según sus facultades y situación;

$2^{\circ}$.- cuando el marido no asegure los aportes de la mujer; 
3\%.-cuando el marido abuse de las facultades que respecto de los bienes comunes le acuerda el C.C.

49. - cuando la mujer no quisiese asumir la administración de la sociedad en los siguientes casos: ción;

a).-si el marido está impedido de ejercerla, por causa de interdic-

b).-si se ignora el paradero del marido, o éste se encuentra en un lugar remoto sin tener apoderado;

c). - si el marido ha sido condenado a una pena privativa de la libertad que produzca la interdicción civil.

E).-DE LA PROPIEDAD HORIZONTAL-

De: Ley Nr 10726 y Reglcmento sobre la propiedsd horizontal. Publicaciones del Primer Juzgado en lo Civil de la Provincia de Huancayo. Pág. 7, 9.

Legislada por Ley $\mathrm{N}^{\circ}$ 10726, promulgada el $1^{\circ}$ de diciembre de 1946 .

Art. $1^{\circ}$.- las secciones en que se divida cada piso de un edificio podrán pertenecer a diferentes propietarios.

Art. 2\%.-cada propietario tendró un derecho exclusivo sobre su sección y de copropiedad sobre las zonas y servicios comunes, contribuyendo a prorrata a los gastos del edificio.

Art. $3{ }^{\circ}$ - - el propietario de un piso o sección de piso podrá hipotecarlo o gravarlo libremente, conforme a la ley común o a la ley del Banco Hipotecario, sin que sea necesario el consentimiento de los otros propietarios. Para ello cada departamento o sección se inscribirá por separado en el Registro de la Propiedad Inmuebles.

\section{DE LA REGLAMENTACION SOBRE LA LEY DE LA PROPIEDAD HORIZONTAL.-}

Aprobada por Decreto Supremo No 25 del 6 de marzo de 1959.

De Ley NP 10726 y Reglamento sobre la propiedrad horizontal Publicaciones del Primer Juzgado en lo Civil do la Provincia de Huancayo-Juez Ciro Rodríguez Arce - Págs. 7, 9. 10, 11. 12. 16 .

Art. 1\%.-La propiedad que se refiere el art. $1^{\circ}$ de la ley 10726, comprende los diversos pisos o departamentos de un edificio que sean independientes y que tengan salida a la vía pública directamente o por pasaje común.

Art. $2 \%$ - - propietario de cada piso o departamento es dueño exclusivo de suyo y copropietario en los bienes y derechos de uso común.

Art. 3․- -son bienes comunes los elementos básicos del edificio en cuanto a construcción, seguridad y conservación del mismo, y los que permiten a los diversos propietarios el goce normal de su piso o departamento. Estos bienes tendrán siempre el carácter de comunes y no pddrón ser enajenados, salvo que lo sean con todo el edificio. 
Art. $4^{\circ}$ - -en el reglamento que se aprobará conforme al art. $15^{\circ}$ se fijará la proporción en el porcentaje que cada uno de los departamentos o pisos corresponde sobre las zonas comunes. Esta proporción será inalterable, aún cuando adquiera en el futuro el piso mayor valor. Esta proporción será válida para la contribución a los gastos que demandan los bienes $Y$ derechos comunes.

Art. 5\%.-el propietario está obligado al pago de los gastos comunes desde que adquirió el departamento, como también aquellos devengados con anterioridad a la adquisición del bien, lo cual no exime al propietario que incurrió en mora, al pago de los adeudado, aún cuando no se ya el dueño del departamento, quedando siempre a salvo la acción de saneamiento a quien corresponda.

Art. $6^{\circ}$.--los derechos del propietario en los bienes reputados como comunes son inseparables del dominio y uso de su respectiva propiedad, por lo que cualquier acto o contrato de ésta comprende también los derechos comunes.

Art. 7\%.-el uso de los bienes comunes no tiene más limitación que el uso legítimo de los demás propietarios sobre estos bienes. Estos no pueden dedicarse a uso distinto de aquel para el cual fueron destinados.

Art. 8\%-el propietario de cada departamento o piso, podrá, sin necesidad del consentimiento de los demás propietarios, enajenar su piso o departamento, pudiendo asimismo, constituir cualquier clase de derechos reales o personales sobre dicho piso o departamento.

Art. 99.-para realizar obra nueva interna o externa que afecte al dominio común o al valor del edificio o mocifique la forma externa de los departamentos se requiere el consentimiento de todos los propietarios conforme al CC (art. 856). El propietario del último piso no podrá hacer edificación alguna en la azotea, aunque por pacto expreso se consideren dueños, sin consentimiento de los demás propietarios.

Art. 10\%.-el ocupante de un piso o departamento ya sea como inquilino o propietario o a cualquier otro título no podrá destinarlo a otro uso distinto que aquel a que se destinó en el momento de la adquisición, salvo consentimiento de los condóminos.

A.t. 11 --cada propietario puede hipotecar su piso o departamento o consibilir sobre él cargas o gravámenes independientemente de los demás propietarios.

Art. 13\%.-en el Registro de la Propiedad Inmueble se inscribirán en una partida matriz además de los actos y contratos trasiativos de dominio comunes en toda unidad inmobilicaria; el conjunto del edificio como todo el detalle de las diferentes partes que lo integran, incluso los bienes comunes, las obras nuevas y el reglamento interno o sus modificaciones. La inscripción de los distintos sectores del edificio que constituya la propiedad horizonial, se efectuaran mediante el sistema de independizaciones, en partida propia, y relacionándola con la partida matriz.

Art. $33^{\circ}$ - -todos los propietarios están obligados a contribuir en proporción, a los gastos de conservación de los bienes comunes y al pago de impuestos y gravámenes. 
F).-DE LA EXPROPIACION FORZOSA.-

Aprobada por Ley $N^{\circ} 9125$, del 4 de junio de $\mathrm{r} 940^{\circ}$

De: compilación de la Legislación Peruana (Concordada. Toma III, págs. 13, 14, 16 .

Art. 1\%.-La expropiación forzosa se decretará por resolución gubernativa expedida con el voto del Consejo de Ministros, expresándose los motivos que justifiquen su necesidad. Se expresará además la dependencia administrativa que debo apersonarse en el proceso de la expropiación.

Art. $2^{\circ}$.- La expropiación se hará previo justiprecio y consignación en moneda nacional. El justiprecio será el promedio entre las tasaciones directas 0 indirectas.

Art. 3‥-Tratóndose de inmuebles urbanos, la expropiación forzosa, comprenderá la totalidad del predio, salvo pacto en contrario.

Art. $8^{\circ}$.-Fijado el precio, ya sea por allanamiento del propietario o por el perito de éste, el expropiante deberá consignar dentro de tercero día el precio.

Art. 9․-Efectuada la consignación el Juzgado ordenará al propietario que otorgue la Escritura Pública de traslación de dominio, designando el Notcrio. El Juzgado puede otorgar dicha escritura en rebeldía.

Art. 17\%.-Todos los gastos que origine el procedimiento, inclusive los honorarios de los peritos serón de cuenta del expropiante.

Art. 19\%.-El ejecutivo podrá delegar en los Concejos Provinciales, Sociedades de Beneficencias, Compañías Fiscalizadas y otras entidades públicas, la facultad de seguir el procedimiento de expropiación.

Art. 20\%. - Las expropiaciones declaradas a favor del Estado y de empresas Inigadoras, y las concesiones de agua se regirón por la presente Ley. (Nota; ver arts. $7^{\circ}$ y $12^{\circ}$ de la Ley 1794). (autoriza al Estado a expropiar terrenos particulares que sean eriazas y promover las inversiones de capitales para la industria agricola).

Art. 23․-Cuando la expropiación se ordene por el Congreso, la resolución Gubernativa que se expida, no requerirá el voto del Consejo de Ministros, ni será motivada.

Art. 24․-Esta Ley regirá para toda clase de expropiaciones, quedando derogadas todas las leyes que se opongan a la presente.

G).-LEY ORGANICA DE PETROLEO.-

Aprobada por Ley 11780 de 12 de marzo de 1952

De Normas Legales. Tomo XVI Primer Semestre 1952. Págs. 72. 73.

Art. 1\%.-Son bienes de propiedad del Estado los yđacimientos de petróleo e hidrocarburos análogos, los cuales son imprescriptibles.

Art. 2\%-La exploración y explotación del petróleo y de los hidrocarburos análogos, su manufactura, refinación, transporte y almacenamiento son de utilidad pública. 
Art. 5․-Por la concesión de explotación o de exploración, el concesionario adquiere el derecho exclusivo de explorar o explotar las sustancias materia de esta ley, durante un plazo determinado y en una área convenida. Las concesiones son bienes inmuebles y confieren derechos reales y pueden ser objeto de hipoteca.

Art. 6\%.-Para los efectos de esta ley, se consideran nacional las compañías constituidas con arreglo al Código de Comercio, y cuyo capital pertenezca a nacionales en un $60 \%$. Siendo Sociedad Anónimas el Directorio lo compongan en su dos tercios por peruanos. Las Acciones serán nominativas y su transferencia serán sólo a peruanos.

Art. $7^{\circ}$.-Las Compañias extranjeras, para solicitar concesiones deberón estar inscritas en los Registros Públicos del Perú y nombrar mandatarios peruanos.

Art. $8^{\circ}$ - - Los Estados y Gobiernos extranjeros, ni las Corporaciones y Compañías que dependan de aquellos no podrán solicitar concesiones por directa ni indirectamente, ni por persona natural o jurídica.

Art. 9?.-Toda persona natural o jurídica extranjera, está prohibida de solicitar concesiones, adquirir o poser, dentro los 50 kilómetros de la frontera, salvo el caso de necesidad, declarada por la ley.

Art. 10\%.-Se encuentran prohibidos de solicitar, adquirir o poseer concesiones, directa $o$ indirectamente en sociedad o individualmente; el Presidente y los Vice-Presidentes de la República; los Ministros de Estado; los Representantes a Congreso; los magistrados judiciales titulares; los funcionarios y empleados del Ministerio de Fomento y en el territorio de su jurisdicción los miembros de las Fuerzas Armadas en actividad y las Autoridades políticas y Municipales. Esta prohibición alcanza a los parientes dentro del cuarto grado de consanguinidad a segundo por afinidad de las personas ya mencionadas.

Art. $11^{\circ}$ - L La prohibición detallada en el art. 10 no alcanza a las concesiones adquiridas en época anterior a la elección o nombramiento de los funcionarios, autoridades y empleados, ni las que adquieran por herencia o legado, ni las que cualquiera de los cónyuges lleve al matrimonio.

Art. 12\%.-Las concesiones están sujetos, sin restricción alguna, a las leyes y Tribunales de la República. Los jueces de Lima son los únicos competentes para conocer los asuntos entre los particulares y el Estado. Los extranjeros hacen renuncia expresa a toda reclamación diplomática.

Art. $13^{\circ}$.-Las concesiones pueden ser materia de cesión o transferencia, previa autorización del Poder Ejecutivo, a favor de quienes reúnan $\mathrm{y}$ cumplan las condiciones y requisitos exigidos por esta ley.

Art. 14‥-Para los fines de esta ley, el territorio de la República queda dividido en cuatro zonas: Costa, Sierra, Oriente y Zócalo Continental.

Art. 102\%.-Toda transferencia de concesiones de exploráción o explotación pagarón un impuesto especial de $5 \%$ adicional a todos los impuestos y alcabalas de carácter general que se calculará sobre el precio pactado o sobre el valor fijado por peritos, sĩ la cesión fuese gratuita. Estón exentos de este impuesto, los aportes para la constitución de compañías.

Art. 16\%.-Una misma concesión no podrá comprender dos zonas.

Art. 17\%.-Las compañías que se organicen en el Perú, con capitales extronjeros, con posterioridad a la presente ley, deberán ofrecer a perua- 
nos el $36 \%$ de sus acciones al tiempo de constituirse. Esta opción durará 90 días, pasados los cuales caducará la opción.

H).-DE LA EMPRESA PETROLERA FISCAL.-

Legislada por Decreto-Ley No. 14473 del 2 de moyo de 1963

De Informaciones Comerciales, Nos. 161/62-abr. may. jun. 1963 págs. 26. 27.

Art. $1 \%$ - Ia Empresa Petrolera Fiscal, es un organismo estatal, con personería jurídica y autonomía propia, se regirá por la ley No. 11780 y la presente Ley. Sus relaciones con el Poder Ejecutivo las mantendrá a través del Ministerio de Fomento y Obras Públicas.

Art. 4 "inc. a).-Entre los fines de la Empresa Petrolera Fiscal se encuentra: el estudio, la exploración y explotación de las áreas y yacimientos de petróleo e hidrocarburos análogos que actualmente tiene otorgados $Y$ todos los que el Estado le cajudique en el futuro en el ejercicio de su imprescriptible derecho de propiedad.

Art. 6\%, inc. a).-La Empresa Petrolera Fiscal está autorizada, para adquirir bienes muebies e inmuebles y ejecutar las obras $y$ celebrar los contratos que sean necesarios, para el cumplimiento de sus fines.

Art. 16\%.-La Empresa Petrolera Fiscal, de conformidad con el art. 104 de la ley No 11780, queda exonerada del pago de todo impuesto o arbitrio, creado o por crearse, excepción de los impuestos que gravan las utilidades de la industria y comercio del petróleo y derivados.

\section{1)._CODIGO DE MINERIA.--}

Promulgado por Decreto-Ley No 11357, del 12 de mayo de 1950.

De Código de Minoría Concordado. Carlos Rodríguez Esscobedo 1955. Págs. 41, 45, 50, 51, 53, 56, 61, 71.

Art. 3\%.-El Poder Fjecutivo concederá a las personas roturales o jurídicas, nacionales o extranjeras de derecho privado que lo soliciten, el derecho para explorar hasta por cinco años o para explotar indefinidamente toda clase de sustancias minerales y fósiles susceptibles de ser industrialmente utilizados, en la forma $y$ con las facultades $y$ obligaciones establecidos en este Código.

Art. 7\%.- La mina es un inmuebles distinto $y$ separado del terreno superficial en que está ubicada, aunque su concesionario sea también el propietario del suelo. Se consideran también inmuebles las cosas destinadas a su permanente explotación, como las construcciones, maquinarias, aparatos, instrumentos, vehículos, etc. Y cuanto se implante en ellas para aplicarlo al fin económico de la concesión, cunque se hallen fuera de su perímetro.

Axt. 9․-Será objeto de una concesión minera distinta, la apertura de una galería o socavón general para facilitar la explotación, transporte, desagüe y ventilación de dos o más minas, que se obliguen a construir los 
concesionarios de éstas, alguno de ellos 0 un extraño, solos o asociados con otro. Se atribuye la calidad de inmueble a estas concesiones.

Art. 13\%.-La concesión minera no es susceptible de división material, cualquiera que sea su naturaleza y extensión.

Art. 14\%.-No podrán solicitar concesiones, el Presidente de la República, los Ministros de Estado, los Directores de Minería y de Petróleo y todo el personal titular, interino, contratado o comisionado de dichas Direcciones $Y$ de sus Cuerpos Técnicos, durante el ejercicio de sus funciones o empleos.

Art. 15?.-Se encuentran también impedidos de solicitar concesiones, las funcionarios y servidores de las personas naturales y corporaciones o dependencias estatales o fiscalizadas que exploren o exploten minas para el Estado o que las contraten con éste.

Art. 16\%.-No podrán solicitar concesiones mineras los miembros del Poder Judicial en el territorio de su jurisdicción y las autoridades políticas y policiales en que ejerzan su función.

Art. 18\%.-No podrán adquirir concsiones mineras por contrato, ni intervenir en la formación de sociedades o sindicatos constituidos para la exploración y explotación, ninguna de las personas comprendidas en los arts. $14^{\circ}, 15^{\circ}$ y $16^{\circ}$ de este Código, mientras ejerzan sus funciones y comisiones. ni sus cónyuges, ascendientes y descendientes.

Art. 21:-Dentro de los cincuenta kilómetros de las frontercis, los extranjeros no pueden adquirir ni poseer, por ningún título, concesiones mineras, directa $o$ indirectamente, en sociedad o individualmente, saivo el caso de necesidad pública, declarada por el Congreso.

Art. 27\%.-La concesión minera otorga un derecho real sobre las sustancias minerales materia de la concesión. Su título es irrevocable e indefinido, como el de la propiedad común y caduca por dejar de pagar las cánones durante dos años consecutivos.

Axt. 35\%.-El concesionario podrá adquirir, previa indemnización, los terrenos superficiales de su concesión que se encuentren cultivados o cercados, si el área respectiva fuera indispensable para la racional utilización de la concesión.

Art. $53^{\circ}$-El pago del canón territorial y del impuesto a las utilidades exonera al concesionario durante veinticinco años a partir de la fecha de promulgación de este Código, de todo impuesto o gravamen creado o por crearse, ya sea nacional, regional o local, así como de cualquier otra tributación sobre concesión.

Art. 236\%.-Las concesiones auriferas otorgadas conforme a la ley No 7601 quedarán sujetas a las disposiciones de la segunda parte del arto $11^{\circ}$ y a los artículos $14^{\circ}$ y $17^{\circ}$ de dicha ley hasta el 31 de dicismbre de mil novecientos cincuentidos. A partir del primero de enero de mil novecientos cincuentitres regirá para dichas concesiones todas las disposiciones de este Código, excepto la del art $51^{\circ}$ que será aplicada a partir del $1^{\circ}$ de enero de mil novecientos cincuentiocho. Los trabajos obligatorios acumulados hasta el treintiuno de diciembre de mil novecientos cuarentinueve por aplicación de la ley $\mathrm{N}^{\circ}$ 7601, podrán servir para pagar el sobre-canon teritorial establecido en el artículo $51^{\circ}$ de este Código hasta sil completa amortización 


\section{7).-CODIGO DE PROCEDIMIENTOS ADUANEROS.-}

Promulgado por Decreto Supremo del 21 de abril de 1926, en uso de la autorización contenida en la Ley No 4380 .

De: Código de Procedimientos Aduaneros Segunda Edición Oficial 1933. Pớg. 106.

Art. $486^{\circ}$.-Las resoluciones que por su tenor explícito no resulten de carácter general, se reputarón aplicables solamente al caso concreto de que tratan.

k).-CODIGO DE AGUAS.-

Promulgado por Ley del 24 de febrero de 1902.

De: Legislación de Agua é Irrigación Anotada y Concordada por Ramón Acosta y Cavero, 1939. Págs. 18, 19, 21, 22, 24,27.

Art. 158\%.-Es necesario autorización para el aprovechamiento de las aguas públicas especialmente destinadas a empresas de interés público o privado, a excepción de las aguas de manantiales y arroyos en cauces naturales, las aguas para los ferrocarriles, aguas pluviales que discurren por barrancos y en los ríos navegables, en cuyos casos no necesitan autorización.

Art. 162․-En las concesiones de aprovechamientos de aguas públicas se entenderá comprendida la de los terrenos de dominio público necesario para las obras de presa y de los canales y acequias. Tratándose de terrenos municipales, del Estado, o de los pueblos, se impondrá la servidumbre forzosa o la expropiación por causa de utilidad pública.

Art. 163\%.-En toda concesión de aprovechamiento de aguas públicas, se fijará la naturaleza de ésta, la cantidad en litros por segundos del agua concedida.

Art. 164\%.-Las aguas concedidas para un aprovechamiento no podrán aplicarse a otro uso diverso sin la formación de expediente, como se tratara de nueva concesión.

Art. 165\%.-La Administración no será responsable de la falta o disminución que pueda resultá en el caudal expresado en la concesión, ya sea que proceda de error o de cualquier otra causa.

Art. 166.- - Siempre que las concesiones de aprovechamiento y en los disfrutes de cantidades determinadas de agua por espacio fijo de tiempo no se exprese otra cosa, el uso continuo se entiende por todos los instantes, si fuese por días, natural se entenderá de veinticuatro horas que comenzará a contarse desde la seis de la mañana; si fuese durante el día, se entenderá de seis de la mañana a seis de la tarde, y si fuese de noche, de seis de la tarde a seis de la mañana, si fuese por semanas se contará de la seis de la mañana del domingo, si fuese por días festivos o con exclusión de ellos, se entenderá los de precepto en que no se puede trabajar, considerándose únicamente días festivos aquellos que eran tales en la época de la concesión o del contrato. 
Art. 167\%.-El derecho al uso del agua se otorga después de todas las formalidades previas, prescritas por el Código de la materia, leyes privativas y su reglamento y las que determinan en la resolución por la que se otorga la concesión. Las concesiones de aprovechamientos de aguas caducarán por no haberse cumplido las condiciones y plazos con arreglo a las cuales hubiesen sido otorgadas.

Art. 169\%,-En toda concesión de aprovechamientos especiales de aquas públicas, se observará el siguiente orden de preferencia:

1). - Abastecimiento de poblaciones.

2). - Abastecimiento de ferrocarriles.

3). -Riegos .

4).-Canales de navegación.

5).-Molinos y otras fábricas, barcas de paso y puentes flotantes.

6).-Estanques para viveros 0 criaderos de peces.

Dentro de cada clase serán preferidas las empresas de mayor importancia y utilidad, y en igualdad de circunstancias, las que antes hubiesen solicitado el aprovechamiento.

Es facultativo del Supremo Gobierno otorgar las aguas cuya concesión se le pide.

Art. 196.-Cuando existan aprovechamientos en uso de un derecho reconocido y valedero. sólo cabrá nuevas concesión en el caso de que de la medida de las aquas en años ordinarios resultare sobrante el caudal, que se solicite, después de cubiertos completamente los aprovechamientos existentes.

Hecha la mesura, se tendrá en cuenta, para determinar la cantidad de agua necesaria, la época propia de los riegos según los terrenos, cultivos y extensión regable. En los años de escasez no podrán tomar el agua, los nuevos concesionarios mientras no estén cubiertas todas las necesidades de los usuarios antiguos.

Art. 220\%.-Cuando un establecimiento industrial comunique a las aguas sustancias y propiedades nocivas a la salubridad o a la vegetación, Concejo Municipal respectivo dispondrá que se haga un reconocimiento facultativo y si resultare cierto el perjuicio, mandará que se suspenda el trabajo industrias hasta que sus dueños cumplan con lo que se les ordene para evitar el daño. Los derechos y gastos del reconocimiento serán satisfecho por quien hiciere la queja si ésta es infundada, caso contrario por el dueño del establecimiento. El plazo para cumplir la medida ordenada será de uno a seis meses, si no cumplen en dicho plazo se entenderá que renuncian a la explotación de su industria.

Art. 246\%.-Para aprovechar en el movimiento de mecanismos fijos la fuerza motriz de las aguas que discurren por un canal o acequia propia de una comunidad de regantes, será necesario el permiso de dicha comunidad. Al efecto se reunirán todos regantes en junta general, y decidirán la mayoría de ellos computados los votos (Los votos se computan, si el votante recibe el agua con sujeción a medida, por el número de las unidades de su dotación: y en caso contrario, por el de la extensión cultivada que el sufragante tenga en su fundo. Los industriales que se sirvan de las aquas comunes, como fuerza motriz o de algún otro modo, no tendrán en las juntas sino un solo voto por establecimiento o empresa, art. $235^{\circ}$ ). De su negati- 
va cabrá recurso ante el Ministro de Fomento, quien oyendo a dicha comunidad podrá conceder el aprovechamiento, siempre que no cause perjuicio al riego ni a otras industrias, a no ser que la comunidad de regantes quiera cprovechar por sí misma la fuerza motriz, en cuyo caso, tendrá la preferencia debiendo dar principio a las obras dentro del plazo de un año.

\section{L) - DE LA INTERVENCION DEL RAMO DE HACIENDA EN LA ADQUISI- CION Y CONTROL DE LA PROPIEDAD INMÓBILIARIA FISCALL.-}

Reglamentada por Decreto Supremo del 4 de junio de 1914.

De: Margesí de Bienes Nacionales. Publicación de la Dirección
de Bienes Nacionales del Ministerio de Hacienda y Comercis.
Tomo XX, 1961. Págs. 405, 406, 414, 416, 417, 420. 426, 427.
430, 431, 432, 433, 437, 438, 439, 440.

Frt. 1\%.-El Ministerio de Hacienda otorgará la escritura definitiva de adquisición de todo inmueble que adquiere el Estado, cualesquiera que sea su objeto.

Frrt. 2․-Los demás Ministerios pasarón al de Hacienda, después de la aprobación Suprema, los expedientes originales que hubieren seguido, para que éste mande extener la correspondiente escritura, con inserción de las piezas que son indispensables para su legal validez.

Art. 3․-Dichos expedientes, además del plano oficial levantado por un ingeniero del Estado y tasación del inmueble o del precio pactado en su adquisición y del Certificado del Registro de la Propiedad Inmueble sobre gravámenes durante 30 años, deberá contener originales también 0 , en su defecto, en copias auténticas, todos los documentos que acrediten la perfecta adquisición del inmueble:

a).-Tratándose de inmuebles adquiridos en remate público, o en adjudicación al Fisco, por cualquiera causa, la Sentencia del Juzgado de Primera Instancia respectivo, de las Cortes Superiores y Suprema, en caso de controversia.

b).-Cuando la adquisición se realice mediante expropiación forzosa; el Decreto Supremo que declaró su necesidad y utilidad y la sentencia ejecutoriada de los Tribunales que ordenó la expropiación.

c).-Si la adquisición se hace de mutuo acuerdo con el dueño, y es el único local aparente para el objeto a que se le distina, se hará constar exprescmente esta circunstancia en la escritura;

d). -Cuando no sea necesaria la ubicación del inmueble en sitio determinado, la adquisición se hará en remate público por medio de propuestas cerradas; publicándose al efecto las bases aprobadas por el Gobierno.

Art. 4․-Estos expedientes servirán de base al Ministerio de Hacienda, para formar la minuta de la escritura, si en la tramitación del expediente notare vicios y omisiones que produjeran nulidad; limitándose en este caso a manifestarlos al Ministerio que lo hubiere enviado, a fin de que proceda $\propto$ subsanarlos. 
Art. $6 \%$ - Estos expedientes con sus respectivos planos y un testimonio de la escritura en que conste la inscripción del contrato en el Registro de la Propiedad Inmueble y que se extenderá precisamente en la Notaría de Hacienda constituirá el título que acredite el derecho de propiedad del inmueble y serán conservados con las seguridades debidas.

\section{JURISDICCION DE LA DIRECCION DE BIENES NACIONALES SOBRE LA PROPIEDAD INMOBILIARIA FISCAL.-}

\section{Aprobada por Decreto Supremo del 10 de febrero de 1947.}

Frt. 1:-La Dirección de Bienes Nacionales del Ministerio de Hacienda informará, revisará y resolverá todos los asuntos relacionados con los bienes del Estado, centralizándose en esta única Dependencia la facultad de atorgar las Escriuras Públicas definitivas en que el Estado sea parte en los contratos que se otorguen $y$ en general tendrá las facultades que las leyes $Y$ disposiciones administrativas vigentes le tienen conferidas al efecto.

Art. 2\%.-Todas las entidades administrativas del Estado quedan obligadas bajo responsabilidad de sus respectivos personeros a dar estricto cumplimiento a las disposiciones contenidas en el Decreto Supremo de 4 de. junio de 1914.

Art. $8^{\circ}$.-La Caja de Depósitos y Consignaciones, Departamento de Recaudación, ni la Superintendencia de Contribuciones dará curso a ninguna minuta relacionada con la adquisición o venta u otras formas de enajenación o afectación del patrimonio inmobiliario fiscal que no lleve el visto bueno de la Dirección de Bienes Nacionales.

Frt. 9\%.-La Dirección General de los Registros Públicos por su parte dictará las medidas conducentes $\alpha$ que se suspenda todo trámite sobre inscripción o anotación de la propiedad inmobiliaria fiscal que no lleve el visto bueno de la Dirección de Bienes Nacionales.

Art. 10\%.-Las disposiciones de este Decreto comprende a las Compañias fiscalizadas y Entidades en general que tengan a su cargo inmuebles de propiedad fiscal, excepto aquellas dotadas de economía jurídica tales como: Las Corporaciones o Bancos de Fomento con capitales del Estado las que se limitarán por esta sola vez a remitir una relación siempre de los bienes inmuebles de su propiedad.

Art. 11\%.-Ninguna Dependencia Administrativa podrá otorgar concesiones de uso, contratos de arrendamientos, de compra-venta, permuta y ningún otro cjénero de actos o contratos sobre inmuebles fiscales, facultad que corresponde exclusivamente al Ministerio de Hacienda por medio de su Repartición respectiva (Dirección de Bienes Nacionales) debiendo en todo caso remitir a éste último, las solicitudes o expedientes que se organicen ante la Dependencia a su cargo. Esta disposición comprende al Ministerio de Marina, al que con arreglo al Reglamento de Capitanías sólo compete remitir el informe técnico en las solicitudes que formulen los interesados en concesiones de uso de terrenos ribereños.

Art. 12\%-Las Escrituras Públicas en que intervenga el Estado deberón extenderse necesariamente ante el Notario de Hacienda de turno. Ni la Caja de Depósitos y Consignaciones, Departamento de Recaudación, ni la 
Superintendencia de Contribuciones tramitarán las minutas que aparezcan presentadas por Notario Distinto.

Las escrituras a que se refiere este artículo, que no sean otorgadas ante el Notario de Hacienda, no producirán efecto ante la Administración Pública, y el Notario que haya intervenido indebidamente está obligado a reintegrar al de Hacienda el doble de los derechos y expensas notariales que hubiere cobrado.

\section{SERA OBLIGATORLA LA VISTA FISCAL EN LOS EXPEDIENTES QUE AFECTEN EL PATRIMONIO DEL ESTADO.}

Aprobado por Decreto Supremo del 31 de mayo de 1949.-

Docreta.- $\mathbf{A}$ partir de la fecha, no expedirá resolución definitiva en los expedientes relacionados con cuestiones que por la importancia de su cuantía o por su naturaleza especial, afecten al patrimonio privado del Estado, sin la previa vista Fiscal en lo Administrativo de la Corte Suprema, la cual pedirá a su vez terminados todos los trámites correspondientes.

\section{FUNCIONES Y ATRIBUCIONES DE LA DIRECCION DE BIENES NACIONALES}

Aprobado por Decreto Supremo del 6 de julio de 1950

Art. 1‥-Es función primordial de la Dirección de Bienes Nacionales, el registro, control, administración y defensa del patrimonio mobiliario e inmobiliario fiscal;

Art. 2\%-Entre las obligaciones y atribuciones de la Dirección de Bienes Nacionales tenemos:

a).-Llevar el Margesí de Bienes Nacionales;

b). - Intervenir en todos los contratos referentes $\alpha$ inmuebles en los que el Estado sea parte;

c).-Aprobar toda venta o permuta de propiedad fiscal, cuando ella sea procedente;

d).-Aprobar toda afectación de uso de propiedad fiscal.

\section{MARGESI DE BIENES NACIONALES.-}

Art. 3․-El Margesi de Bienes Nacionales comprende:

a). - El Margesí de Bienes Inmuebles; $y$

b).-El Margesí de Bienes Muebles.

\section{MARGESI DE BIENES INMUEBLES.-}

Art. $4^{\circ}$ - Este Margesi se lleva̛á mediante inscripciones manuscritas en Libros Matrices y comprenderå:

a). -El Libro de Predios;

b). -El Libro de Naves;

c). -El Libro de Ferroccorriles; $y$

d). - Fl Libro de Muelles y Diques. 


\section{INTERYENCION EN LOS CONTRATOS SOBRE INMUEBLES.-}

Art. 34-Todos los Ministerios pueden aprobar la compra de Inmuebles, pero hecha la aprobación, deben remitir el expediente respectivo a la Dirección de Bienes Nacionales para que redacte la minuta correspondiente o para que exprese su aprobación a la que se haya preparado;

Art. $35^{\circ}$.-No se otorgará ninguna escritura de compra mientras el vendedor no presente copia leteral de dominio y certificado de gravámenes expedidos por el Registro de la Propiedad o en defecto de la inscripción. títulos suficientes para acreditar fehacientemente su propiedad;

Art 30\%-Todas las escrituras de compra de Bienes por el Estado, deben otorgarse ante el Notario de Hacienda;

Art. 37\%.-La Caja de Depósitos y Consignaciones, Departamento de Recaudación, ni la Superintendencia de Contribuciones, darón curso a ninguna minuta de campra que no lleve la aprobación de la Dirección de Bienes Nacionales.

Los Notarios tampoco elevarán a escritura pública las minutas que no lleven esa conformidad.

Art. 39\%.-Toda compra debe ser aprobada por Resolución Suprema.

\section{VENTA O PERMUTA DE PROPIEDAD FISCAL.-}

Art $40^{\circ}$-Toda venta o permuta de propiedad fiscal debe ser aprobada por Resolución Suprema expedida por la Dirección de Bienes Nacionales, siendo nulas las aprobadas por Reparticiones diferentes.

Art. 41\%.-Las ventas, salvo los casos autorizados por las leyes especiales y las permutas sólo se acordarán por iniciativa del Ejecutivo de acuerdo con sus intereses y sus necesidades, quedando prohibida la tramitación de tada solicitud de particulares para la celebración de esos contratos;

Art. 42 .- La venta de propiedad fiscal, salvo los casos señalados en leyes especiales, deben hacerse en pública subasta, ante las Juntas Departamentales de Almonedas, sirviendo de base la primera convocatoria, el valor total de la tasación practicada por el Perito nombrado por la Junta, y en las otras convocatorias, se rebajará en $10 \%$ la base de la convocatoria.

Art. $43^{\circ}$ - - La Subasta deberá ser aprobada por Resolución Suprema expedida por la Dirección de Bienes Nacionales, para que pueda otorgarse la escritura d venta a favor del mejor postor;

Art. 17\%,-El Fiscal en lo Administrativo de la Corte Suprema debe pronunciarse en todos los expedientes sobre venta o permuta de propiedad fiscal, antes de expedirse la Resolución Suprema que les ponga término.

\section{AFECTACIONES DE USO.-}

Art 49:-Las afectaciones de uso de propiedad fiscal, sólo pueden ser otorgadas por la Dirección de Bienes Nacionales y por Resolución Suprema.

Toda afectación acordada por Repartición diferente es nula. 
Art. 50\%-Las afectaciones de propiedad fiscal sólo pueden otorgarse a favor de las Reparticiones del Estado para el funcionamiento de su Dependencia $\circ$ a favor de particulares que desempeñen una labor que signifique una colaboración con la función social del Estado.

Árt. 51\%.-En toda afectación de uso, se indicará el fin para el que se otorga y la Dirección de Bienes Nacionales procederá a reasumir la administración del bien tan pronto deje de ser aplicado a ese fin:

Art. 53\%.-Cuando se trate de formalizar por escritura pública las afectcciones de uso a favor de particulares, deben otorgarse ante el Notario de Hacienda y la Caja de Depósitos y Consignaciones, Departamento de Recaudación, ni la Superintendencia de Contribuciones, darán curso a ninguna minuta de afectación de uso que no lleve la aprobación de la Dirección de Bienes Nacionales. Los Notarios tampoco elevarán a escritura pública las minutas que no lleven esa conformidad.

Art. 54\%.-La Dirección de Bienes Nacionales llevará un Registro especial de las afectaciones de uso.

\section{ARRENDAMIENTOS.-}

Art. 55․-Sólo la Dirección de Bienes Nacionales puede otorgar con-. tratos de arrendamiento de propiedad fiscal, siendo nulos los otorgados por otras reparticiones;

Art. 56\%.-Los arrendamientos se otorgarán por Resolución Ministerial cuando la merced conductiva señalada no exceda de $S \mid .2,500.00$ al año y por Resolución Suprema cuando excedan de esa cantidad;

Art. $58^{\circ} .-$ A ningún arrendamiento se le podrá fijar una duración superior a diez años;

\section{REGLAMENTO PARA LA ORGANIZACION Y FUNCIONAMIENTO DE LAS JUNTAS DEPARTAMENTALES DE ALMONEDAS.-}

Aprobada por Decreto Supremo No 2 del 21 de noviembre de 1956.

Ert. 1․-Las Juntas de Almonedas de cada Departamento serán presididas por el Prefecto e integradas, excepto en el Departamento de Lima, por el Vocal y Fiscal menos antiguos de la respectiva Corte Superior, el Tesorero, Fiscal y el Notario de Hacienda o el Notario más antiguo de la lacalidad si no hubiere uno de Hacienda nombrado:

En los Departamentos que no hubiere Corte Superior, el Vocal y Fiscal serán reemplazados por el Agente Fiscal y el Alcalde del Concejo Provincial del Cercado.

Art. 29.-La Junta de Almonedas del Departamento de Lima, será presidida por el Prefecto e integrada por el Director de Bienes Nacionales, el Sub-Director de Administración del Ministerio de Hacienda, un delegado de la Contraloría General de la República con categoría de Oficial, el Notario de Hacienda de turno y el Sub-Director de Bienes Nacionales.

Art. $3 \%$-Las Juntas de Almonedas necesitan para su funcionamiento la concurrencia de tres de sus miembros por lo menos, debiendo presidirlas, en ausencia del Prefecto, el nombrado en segundo término. 


\section{FUNCIONAMIENTO.-VENTA.}

Art. 5--Recibida la transcripción de la Resolución Suprema que ordene una venta en pública subasta, el Prefecto convocará a la Junta para dar cuenta de elia y proceder al nombramiento de los peritos que practiquen la tasación del bien $a$ venderse:

Ari. 6:--Presentada la tasación y aceptada por la Junta, se aprobarớ las Bases de la Subasia y se fijará la fecha para la misma, previa publicación de avisos por un término de veinte días.

F:t. 7\%.-En las subastas en el Departamento de Lima los avisos deben publicarse en el Diario Oficial "El Peruano", sin perjuicio de los que acuerde publicar en los otros diarios. En los otros Departamentos, los avisos se publicarón en el diario de mayor circulación.

Art. $8^{\circ}$.-Cuando el bien esté ubicado en lugar diferente de aquel en que se efectúe la subasia, ésta se anunciará también por carteles colocados en el inmueble.

Art. $9^{\circ}$.- - En los avisos y en los carteles se indicaró, según el caso, la naturaleza del bien, características, ubicación, área, lugar, día y hora de la subasta, precio base de la misma y la oficina donde los interesados pueden conocer las Bases respectivas. bien;

Frt. 10\%. El precio de la subasta sezá el íntegro de la tasación del

Art. 11\%.-Si en la primera convocatoria no hubjere postores, se procederá $\alpha$ subsiguientes convocatorias, rebajando para cada una de ellas en diez por ciento el precio base de la convocatoria anterior:

Art. 13․-Para ser postor se requiere depositar el seis por ciento del precio base da la subasta, en la Caja de Depósitos y Consignaciones a la orden de la Junta Departamental de Almonedas o ante la misma Junta en efectivo, en cualquier momentto, mientras esté abierta la subasta y antes que el postor haga su primera postura:

Frt. 14‥-Este depósito seró devuelto inmediatamente de terminada la subasta, quedando retenido sólo el del subastador, en garantía del pago del precio: basta;

Art. 17\%.-Adjudicado el remate, no pracede la reapertura de la su-

Art. 18\%.-Terminada la subasta la Junta elevará al Supremo Gobierno la tasación del bien, los avisos publicados y copia de las Bases y las Actas, para la aprobación correspondiente;

Art. 199.-Recibida la transcripción de la Resolución Suprema que aprueba la Subasta, el Prefecto notificará directamente al subastador para que dentro de los quince días siguientes cancele el precio de compra, bajo pena de dar por abandonado el remate, con pérdida a favor del Estado del seis por ciento empozado.

LL). - LEYES . -

1). - Ley de Timbres de 1879 (artículo 11\%), puesta en vigor por la Resolución Suprema de 4 de julio de 1899, que señala los casos de aplicación del imputo (art. 812 CC.: las tierras, minas y aguas públicas. Los Pre- 
dios. Las Minas concedidas a los particulares. Las Naves y aeronaves. Los ferrocarriles y sus vías. Los muelles y los diques. Las concesiones y autorizaciones para explotar servicios públicos. Los derechos sobre inmuebles, inscribibles en el registro de la propiedad.).

2).-Ley de ventas a plazos, de 14 de noviembre de 1900 , que exonera de impuestos las ventas a plazos de inmuebles, verificadas dentro de ciertas condiciones.

3).-Resolución Legislativa NI 2726, del 15 de marzo de 1918, que aclara el artículo $11^{\circ}$ de la ley de 1879 , en el sentido de que cuando las cosas muebles que se refiere el art. $456 \mathrm{CC}$. ins. $2^{\circ}$, se encuentren adheridas a un inmueble deben pagar el medio por ciento de impuesto de enajencución.

3a). -Ley No 1794, de 4 de enero de 1913, se puede exonerar de toda clase de impuestos a las empresas o sociedades que lleven acabo obras de irrigación, colonización y anexas.

4). - Ley No 4452 del 2 de enero de 1922, que establece que las transferencias de concesiones de explotación estarán gravadas con el $5 \%$ del precio pactado, sin perjuicio del derecho de alcabala.

5). - Ley $N^{\circ} 4781$ de 9 de enero de 1924. que eleva del $2 \%$ al $4 \%$ la tasa del impuesto.

6).-Ley No 5004. de 6 de enero de 1925, sobre procedimiento en la acotación y pago del impuesto.

7).-Ley No 6051, de 27 de febrero de 1928 (art. 19) y Ley Nং 8128 de 7 de noviembre de 1935 art. 27\%), que exonera del pago del impuesto a las Sociedades de Beneficencia, así como a los bienes que poseen o administran .

8).-Ley No 6619 de 9 de marzo de 1929, (arts. 13 y 14) que declara exonerados de impuesto los contratos sobre construcción de casas para empleados y obreros.

9).-Ley No 6809, de 28 de febrero de 1930, que señala casos de aplicación $Y$ excepciones en el pago del impuesto.

10). -Decreto-Ley $N$ N 7144. de 5 de mayo de 1931. que exonera de alcabala al capital que se aporta en bienes inmuebles a la constitución de Sociedades.

11). -Decreto Ley No 7264, de 11 de agosto, de 1931, que es indispensable acreditar el pago del impuesto predial para tramitar actos de traslación de dominio de un inmueble.

12). - Ley No 7601 de 18 de octubre de 1932, que la transferencia de concesiones auríferas, estan sujetas al pago del impuesto.

13). - Ley No.8128, de 7 de noviembre de 1935. que las Sociedades de Beneficencia y Cajas de Ahorros, gozarán de las exoneraciones que les acuerda las leyes vigentes $Y$ demás disposiciones.

14).-Ley No 8433 de 12 de agosto de 1936. (inc. a) del art. 67\%, que exonera de alcabala la adquición o transferencia de inmuebles de la Caja Nacional del Seguro Social.

15).-Ley No 8548, de 17 de junio de 1937, que la Sociedades Anónimas, que se constituyan con bienes que representan el patrimonio de una persona individual o entre parientes o entre cónyuges, deberán emitir acciones nominativas. 
16). - Ley No 8708; de 21 de julio de 1938. que exonera de alcabala la tramsferencia de terrenos ó de inmuebles que tienen por objeto la construcción ó el establecimiento de hoteles.

16a). - Ley 9140 de 14 de junio. Faculta Poder Ejecutivo conceda exoneraciones para industrialización del País.

17). - Ley No 10318, de 13 de diciembre de 1945. que exonera de impuestos a los asilos de ancianos establecidos por la Hermanitas de los Ancianos establecidos en el territorio nacional.

18) - Ley No 11319, de 20 de marzo de 1950, que exonera de impuesto de alcabala los inmuebles adquiridos por el Ministerio de Guerra.

19).-Ley No 10723, de 26 de noviembre de 1946, que eleva en medio por ciento la alcabala sobre los inmuebles de Lima y Callao.

20).-Ley No 11166, de 16 de setiembre de 1949, se eleva a un $1 \%$ la tasa del impuesto de alcabala de los predios rústicos y urbanos de la República.

20a). - Ley No 11551 de 31 de diciembre de 1950, declarando de interés público y necesidad nacional la reconstrucción del Cuzco, y exonerando de impuesto de alcabala las escrituras que se celebren con tal fin.

21). -Ley No 12370, de 8 de junio de 1955, que exonera a las Empresas que se dediquen a la construcción de casas de bajo costo en urbanizaciones de tipo popular.

22). -Ley No 12813, de 6 de marzo del957. las Ásociaciones Mutuales de Crédito para Viviendas están exentos de impuestos.

$22 \alpha)$.-Ley No 12956, de 21 de tebrero de 1958. libera de impuestos a los terrenos y edificios que se dediquen $\alpha$ Museos.

23). - Ley No 13300, de 18 de enero de 1960, exonera de Impuestos los contratos de la Caja de Retiro de Empleados Públicos (CREP).

24). - Ley No 13309, de 29 de enero del960. los Bonos del Tesoro, tienen valor cancelatorio por impuestos.

25). -Ley No 13417, de 8 de abril de 1960, exonera de impuestos $\alpha$ las Universidades.

26). -Ley No 13428, de 9 de mayo de 1960, exonera de impuesto a la Corporación Departamental de Servicio Eléctricos de Lambayeque.

26). - Ley No 13499, de 20 de enero de 1961, exonera de impuestos $\alpha$ la Corporación de Saneamiento de Arequipa.

27). -Ley No 13500, 26 dè enero de 1961, exonera de impuestos por 10 años a las Ásociaciones de Servidores Públicos y Particulares con fines de construcción y adquisición de viviendas.

28). - Ley No 13517, de 14 de febrero de 1961, (Ley Orgánica de Barrios Marginales) exonera de impuesto la primera transferencia de dominio al amparo de esta ley.

29). - Ley No 13740, de 30 de noviembre de 1961, exonera de impuestos a la Corporación de Desarrollo y Fomento de Tacna.

30). - Ley $\mathrm{N}^{\circ}$ 13514, de 8 de febrero de 1961, exonera del impuesto $\alpha$ las adquisicones que realicen las Compañías Nacionales de Transporte Aéreo con aval i/o fianza del Estado.

31).-Ley 13771, de 19 de diciembre de 1961, exoneración a SENATI, Servicio Nacional de Aprendizaje y Trabajo Industrial.

$31 \alpha)$. - Ley 13778 de 20 de diciembre de 1961, que exonera de im. 
puestos a la Corporación de Fomento y Promoción Social de Puno.

32).-Ley No 13840, de 11 de enero de 1962, exonera de impuesto $\alpha$ las Cooperativas de Viviendas.

33). - Ley No 13908, de 25 de enero de 1962. Las adquisiciones del Servicio Especial de Salud Pública se encuentran afectas al pago de alcabala.

33a).-Ley No 14034, de 6 de marzo de 1962, que exonera del alcabala la adquisición del inmueble que ocupa el Club Äpurímac.

34).-Ley No 14055, de 2 de abril de 1962. exonerando del impuesto las adquisiciones de inmuebles de las compañías de Bomberos.

35).-Decreto-Ley No 14186, de 21 de agosto de 1962, estableciendo sanciones a las infracciones tributarias.

36). - Decreto-Ley $N$ \% 14241, de 20 de noviembre de 1962, exonerando de impuesto al Banco de la Vivienda del Perú.

37). -Decreta-ley No 14390,31 de enero de 1963, exonerando de impuesto a la Junta Nacional de la Vivienda.

37a). -Decreto-Ley No 14391 de 31 de Enero de 1963. declárase de utilidad $y$ necesidad pública $y$ de conveniencia nacional, el establecimiento de urbanizaciones de interés social que realicen la Junta Nacional de la Vivienda y el Banco de la Vivienda del Perú.

38).-Decreto-Ley No 14392, de 31 de enero de 1963, que exonera a las Entidades que realicen programas de vivienda de interés social.

39a). - Ley No 14444 de 28 de marzo de 1963, exonerando de alcabala, la zona inicial de aplicación de la Reforma Agraria en el departamento dèl Cuzco, los valles de Lares y la Convención.

39).-Decreto-LeI No 14413, de 21 de febrero de 1963. Las Donacionez al Ministerio de Educación Pública no están sujetas al pago de impuestos. 40). - Decreto-Ley No 14472, de 2 de mayo de 1963, que exonera de cl. cabala el terreno adquirido por la Congregación del Buen Pastor.

41). -Decreto-Ley No 14473, de 2 de Mayo de 1963, exonerc de impuesto a la Empresa Petrolera Fiscal.

42). -Decreto-Ley No 14485, de 16 de mayo de 1963, que exonera a la Corporación de Reconstrucción y Desarrollo del Departamento de Ica.

42a). -Decreto-Ley $\mathrm{N}^{\circ}$ 14502, de 30 de mayo de 1963, declarando que la Corporación Nacional de Fertilizantes, están exoneradas de impuesto de alcabala.

43).-Decreto-Ley No 14503, de 10 de junio de 1963 que exonera los contratos que celebren las Asociaciones Pro Vivienda "Mariscal Castilla", "Almirante Grau" y "Jorge Chávez".

44). -Decreto-Ley No 14509, de 14 de junio de 1963, que exonera de impuesto al Banco de Fomento Ágropecuario del Perú.

45).-Decreto-Ley $\mathrm{N}^{\circ}$ 14510, de 14 de junio de 1963, que extonera de impuesto al local del Club Cajamarca, de esta capital.

46).-Decreto-Ley $\mathrm{N}$ : 14512, de 14 de junio de 1963, que exonera de impuesto al Club Ancash, para la adquisición de su propio local.

46a).-Decreto-Ley No 14513, de 14 de junio de 1963, exonerando de alcabala, la escritura de adjudicación de un terreno al Club Tennis "Las Terrazas de Miraflores.

47).-Decreto-Ley No 14528, de 20 de junio de 1963. El Seminario de Santo Toribio, queda exonerado de todo impuesto. 
48). - Decrelo-Ley No 14530, de 20 de junio de 1953 que crea la Comisión Permạnente para el estudio de la Legislación Tributaria (Comisión Revisora de la Legislación Tributaria).

49). -Decreto-Ley № 14535 , de 27 de junio de 1963 que exonera de impuesto a la Asociación Inmobiliaria Magisterial (AIM).

50).-Decreto-Ley No 14562, de 11 de junio de 1963, que exonera de impuesto la contratación de adquisiciones de unidades de patrullas navales con el Sindicato Financiero Británico, que representa la Firma Anthony Gibbs \& Sons, Ltda. Londres.

51).-Decreto-Ley $N^{\circ}$ 14576, de 25 de julio de 1963, que exonera de impuesto a la Escuela de Administración de Negocios para Graduados.

52).-Decreto-Ley No 14598, de 25 de julio de 1963, que exonera de impuesto de alcabala a la "Alianza Francesa".

53). -Decreto-Ley No 14602 , de 25 de julio de 1563, que exonera de impuesto las donaciones a la Biblioteca Nacional.

54). - Ley No 14676. de 17 de octubre de 1963. inc. g. que crea rentas para la Corporación de Rehabilitación y Desarrollo Económico del Departamento de Moquegua.

$54 a$ ). - Ley $N: 14700$, de 11 de noviembre de 1953, que aumenta en $1 \%$ la tasa del impuesto de alcabala a los contratos que se celebren en el Departamento de Junín.

$55 a)$.-Ley $N^{\circ} 14750$. de 11 de diciembre de 1963, exonerando de impuesto de alcabala, al Centro Social Tarma.

55). - Ley No 14771, de 20 de diciembre de 1963, que exonero de impuesto las donaciones al Estado para los establecimientos penales y de tutela.

56).-Ley No 14816, de 16 de enero de 1964, Ley Orgánica del Presupuesto Funcional de la República del Perú.

56a). - Ley No 14858, de 7 de febrero de 1964, que da fuerza de ley al Decreto-Ley INo 14530 que crea la Comisión Revisora de la Legislación Tributaria, nombrando los integrantes de dicha comisión, como también sus: atribuciones. Creando ademós la Dirección General de Estudios Tributarios y señalando sus funciones.

Art. 27.-_estbleciendo que las disposiciones relativas al Ingreso, no podrán crenr a moclificar leyes tributarias, pero sí podrán derrogar aquellas curra recoudación sea inferior a $\mathbf{S}$. 500,000.00. República.

Art. 67,-señalando las atribuciones de la Contraloría General de la

Art. 70.-Prohibiendo toda asesoría legal o contable a los empleados - funcionarios de la Contraloría General de la Repúbzlica.

Art. 77.-La Contraloría General de la República elevará mensualmente a las comisiones de las cámaras las cuentas detalladas de la recaudación del mes anterior.

Art. 109.-Sólo para el Servicio Público la ley podrá cerrar, alterar o suprimir impuestos. No hay privilegios personales en materia de impueatos. Los impuestos se pagan en efectivo y en las oportunidades que señala la ley.

57). -Ley N? 14930, 29 de febrero de 1964. Ley Anual del Presupuesto Funcional para 1964 . 
Art. 30.-Ló devolución de impuestos pagados indebidamente será por Resolución del Superintendente de Contribuciones cuando no exceda de S. 300,000.00 y por Resolución Ministerial cuando supere dicha suma.

Art. 33.-Las solicitudes de liberaciones de derechos aduaneros, se regirón por la Ley $\mathrm{N}^{\circ}$ 14816, en sus artículęs 110 á 113 .

Art. 46.-Es responsabilidad del Ministro, Director o funcionario, que autorice una liberación, no facultada por la Ley.

58).-Ley No 14947, de 6 de marzo de 1964, que crea la Corporación de Turismo del Perú, y exonera de impuesto la transferencia de bienes de los hoteles de propiedad del Estado administrado por la Cía. Hotelera del Perú a favor de dicha Corporación.

59).-Ley No 15002, de 8 de abril de 1964, que prorroga por 10 años, a partir de 23 de mayo 1964, los efectos de la ley $N^{\circ} 11867$, que exoneró de impuesto al Departamento de Madre de Dios.

60).-Ley No 15036, 20 de mayo de 1964, que exonera de impuesto $\alpha$ la transferencia de Departamentos de Unidades Vecinales.

61).-Ley No 15122, 7 de agosto de 1964, que exonera de impuesto al parque industrial del Cuzco.

62).-Ley No 15225. 23 Noviembre 1964, aumenta tasa a 6\% sobre transporte de inmuebles, acciones o derechos sobre los mismos, venta de naves, aportes de inmuebles a Sociedades y adjudicaciones de los mismos por reducción o disolución de sociedades; y aumenta la tasa al $5 \%$ sobre transferencia de bienes muebles; grava también la declaración de verdadero comprador.

63).-Ley 15270 (Ley General de Cooperativas) da I de Diciembre de 1964. Sin perjuicio exenciones establecidos por otras leyes, están exonerados de todo impuesto, tasa o orbitrio, vigentes o futuro (art. 66) inc. e.

64).-Ley 15600, 4 Set. 1965 - 4 de Setiembre 1965: (art. 5 inc. $\alpha$ ). Exonera Zona Selva.

65).-Ley 15624, 24 de set. 1965.'Exonera Impuestos donaciones Organismos. Sistema Nacional de Cultura.

66). - Ley 15756 de 30 de Noviembre de 1965, exonera de impuestos por cinco años a los propietarios afectados por deslizamientos Cerro San. Jerónimo, Provincia de Lucanas.

67.-Ley 15679, de 6 de Diciembre de 1965, creando el Parque Industrial de Huancayo $y$ estableciendo exoneraciones.

68).-Ley 15794 de 15 de Diciembre de 1965, creando exoneraciones de transferencia de inmuebles Corporación del Departamento de La Libertad.

69).-Ley 15850 del Presupuesto Anual de 31 de Diciembre de 1965 a) Las devoluciones de impuestos y derechos pagados indebidamente 0 con exceso por los contribuyentes se harán con cargo a la respectiva partida del Título de Ingresos del Presupuesto Funcional de la República, mediante resoluciones en cada caso, del Superintendente Nacional de Contribuciones o del Superintendente General de Aduanas, cuando la cuantía devuelta no exceda de S/. 50,000.00 y del Ministerio de Hacienda y Comercio cuando supere dicha cuantía (art. 129).

b) Autoriza al Ministerio de Hacienda y Comercio a efectuar auditorías de 
muestreo para comprobar correcta aplicación de las leyes tributarias (art. 147).

c) Prohibe bajo responsabilidad la liberación de impuestos o gravámenes

d) Establece que para iniciar acciones judiciales por cobro de impuestos, debe agotarse la vía administrativa y consignar el pago, sin cuyo requisito los juecęs no la tramitarán

\section{M).- DECRETOS SUPREMOS}

1.-1 de mayo de 1916. (Disposición Suprema) que exonera las declaraciones de verdadero comprador.

2). -17 de junio de 1922. que exige para el pase de minutas de transferencia de concesiones mineras a petrolíferas la visación de la Dirección General de Minas.

3). -30 de setiembre de 1936.

3a). -21 de setiembre de 1936. la exoneración de alcabala de enajenaciones sólo procede cuando la concesión de irrigación es otorgada por el Supremo Gobierno a tenor del artículo 199 del código de aguas y a la ley No 1794 .

4).-8 de julio de 1942. que dispone que las donaciones entre vivos no estón sujetas al pago de alcabala de enajenaciones sino al impuesto a las sucesiones.

5).-15 de setiembre de 1942, que establece que los contratos celebrados con el Estado, en que concede exoneración de impuesto, deben ser previamente informados por la Superintendencia General de Contribuciones.

6). - 19 de julio de 1945, en los contratos de compra de inmuebles por el Estado pueden ser exonerados del impuesto por Resolución expresa. Cuando el Estado vende, puede el comprador pagar la mitad del impuesto.

7). -30 de enero de 1948, que establece que la acotación del impuesto correrá a cargo de la Superintendencia de Contribuciones.

8).-15 de Ábril de 1945, Exonera de Impuestos a las Corporaciones con capital aportado por el Estado.

9). - 8 de setiembre de 1948, en caso de que el precio se pague en moneda extranjera, para liquidar el impuesto se tomará el tipo de cambio libre.

10):-16 de febrero de 1950, que pueden ser exonerados del impuesto de alcabala los inmuebles que adquieran los Gobiernos extranjeros para residencia oficial, embajadas o delegaciones.

11). -2 de diciembre de 1950, que exonera de impuesto de Alcabala a la Compañía Constructora "El Hógar Militar" S. A.

12).-18 de febrero de 1954, que exonera del $50 \%$ del impuesto de alcabala sobre la transferencia que realicen los Gobiernos Extranjeros.

13). - 1 de abril de 1954 .

14). - 30 de abril de 1954, dispone que la transferencia de acciones nominativas dentro de los cinco años de emisión o su conversión en acciones al portador, se gravarán con el impuesto de alcabala.

15). - 21 de enero de 1958. Las Entidades Acotadoras y Recaudadoras no darán pase a contratos sin previo pago del impuesto, la Caja de De- 
pósitos y de Consignaciones, Departamento de Recaudación, establecerá una oficina en la Superintendencia de Contribuciones.

16). - 10 de marzo de 1960, la Empresa Recaudadora y la Administración Tributaria serán responsables por la tardanza injustificada o por negligencia en la recaudación.

17). - 27 de enero de 1961, exoneración de impuestos a las empresas que se dediquen a construcción de viviendas.

18). -21 de julio de 1961, exoneración de impuesto al cmparo de la ley de Barriadas en la primera transferencia, previa visción de la minuia por la Corporación de la Vivienda.

19). - 6 de octubre de 1961, los contratos de venta por Empresas Urbanizadoras populares o que construyan viviendas popuiares para empleados $\mathbf{u}$ obreros están exonerados de impuesto.

20). - 27 de octubre de 1961 , los contratos de venta de inmuebles para personal de empleados y obreros, están exentos de impuestos.

21). -3 de noviembre de.1961, exonera a Cooperativas al amparo de la Ley 12813 (Asociaciones Mutuales de Créditos para Viviendas), si se dedican a los fines de la Ley 12370 (Construcción de casas de bajo costo en urbanizaciones populares).

22). - 17 de noviembre de 1961, exonera de impuesto a la transferencia de cascis por el Instituto de la Vivienda.

23). -27 de abril de 1962 exonerando al contrato con Mitsui \& Co. Ltda. y Electric Power Development Co. Ltda. para electrificación e irrigación de Tacna.

24). - 1 de junio de 1962, exonerando de impuesio a las Empresas que construyan viviendas populores.

25). -18 de mayo de 1962, exonerando al contrato con Penedile Peruana S.A. sobre la irrigación La Joya.

26). - 25 de mayo de 1962, exonerándo de impuesto al contrato con el Consorcio formado por las firmas The English Electric Company Ltda. de Londres, Siemens-Schuckertwerke Aktiengesellsehait de Alemania y Georço Wimpey and Company Ltda. de Londres para la construcción de la Central Hidroeléctrica del Mantaro.

27). - 1 de junio de 1962, exonerando la transferencia de inmuebles construídos por la Corporación de la Vivienda.

28). - 15 de junio de 1962, exonerando de impuesto a la Empresa $\mathrm{Na}$ cional de Ferrocarriles del Estado. del Perú.

29). - 18 de junio de 1962, exonerando de impuesto al Bancó Industrial

30). - 10 de enero de 1964, ampliado por R.S. de 20 de setiembre de 1964, derogando por R.S. LOO-H de 11 de mayo de 1964, D.S. de 3 de abril de 1964, amplía la zona de exoneración, a la zona selva por 10 años.

31). - 18 de febrero de 1964. No 12, extendiendo a quince años la exoneración de impuesto a la construcción de viviendas del tipo " $A$ " $y$ " $B$ ".

32). - 18 de febrero de 1964, $\mathrm{H}^{\circ}$ 13, las Capitanías de Puerto no tramitarán transferencia, si no está acreditada el pago de impuesto.

33). - L de marzo de 1964, las empresas aue intervengan en programas de casas populares con garantía de Agency for International Developmet y bajo la administración del Banco de la Vivienda, están exonera- 
das de impuesto de alcabala.

34). -28 de febrero de 1954, que crea el Tribunal Fiscal.

35). -5 de junio de 1964, exonera de impuesto a la construcción del Parque Indusirial en la Provincia de Arequipa.

36).--5 de junio de 1964, No 99-H, exonera a las escrituras de casas construidas con préstamos del Banco Central Hipotecario.

37). - 17 de julio de 1964, se exonera de impuesto a la Mutual Vivienda, por aplicación de la ley 13500.

38). - 14 de agosto de 1964, No 172-H, exoneración al parque industrial de Tacna.

39). - 22 de enero de 1965, No 12-H, son de aplicaciones exoneraciones establecidas por D.S. No 99 de 5 de Junio de 1964 a préstamos que concede el Banco Central Hipotecario del Perú conforme Ley 15143.

140). -19 de febrero de 1965. 35-. Reglamenta Ley N: 15225.

41):-6 de julio de 1965, 224-H, exonerando de impuestos

42). -6 de julio de 1965, exonerando de impuesto a los préstamos para construcción de viviendas de interés social.

43). - 13 de julio de $1965 \mathrm{~N} \div 249-\mathrm{H}$, exonerando de impuestos a los constructores, financiadores, vendedores de viviendas financiadas por AID y administradas por el Banco de la Vivienda del Perú.

44). -4 de octubre de 1965, No 401-H, determinando zonas de la Selva comprendidas en exoneraciones concedidas por la ley 15600.

\section{N).-RESOLUCIONES SUPREMAS.-}

1). -19 de noviembre de 1853, que establece que las ventas que los coherederos hagan a personas extrañas pagan alcabala.

2). -21 de noviembre de 1853, y

3). -19 de octubre de 1872, que exoneran de alcabala la división $Y$ partición las ventas entre coherederos con el objeto de igualar las porciones.

4). -17 de julio de 1863, que dispone que la venta de los bienes situados en el extranjero no pagan impuesto.

5).-21 de junio de 1365, sobre el modo de computar la alcabala en las ventas enfiteúticas.

6). -5 de enero de 1888 ,

7). $\rightarrow 18$ de julio de 1906 ,

8). -13 de octubre de 1909, y

9). - 18 de setiembre de 1919, que establecen que la rescisión de contratos de compra-venta debe pagar alcabala.

10). -12 de julio de 1888. que establece que, cuando el marido ha dispuesto de bienes propios de la mujer y los paga él o sus herederos, se cobra alcabala por la transferencia.

11). - 15 de julio de 1889, que exonera de alcabala las ventas entre los coherederos que no son condóminos.

12).-17 de octubre de 1889, que dispone el pago del impuesto por la ventas de inmuebles situados en la República, que se celebren en el extranjero. 
13). -24 de octubre de 1889, que dispone que la cesión de un inmueble en pago de una deuda está sujeta al impuesto.

14). - 21 de noviembre de 1889, que dispone que los censos y demás gravámenes que, por su naturaleza, se deducen del valor del inmueble, no deben computarse en la fijación del precio sujeto a impuesto.

15). - 10 de julio de 1890, que establece que el pacto de retroventa no es una condición que suspende la cobranza de alcabala; pero que el cumplimiento de la retroventa está exonerado de impuesto.

16). -6 de setiembre de 1890 .

17). -3 de febrero de 1909, $y$

18). -12 de enero de 1916, que dispone que están exonerados de impuesto los actos de ejecución de un derecho de retracto.

19). - 25 de abril de 1892, que establece que, en los contratos en que intervenga el Estado, no se paga alcabala, si se hace constar expresamente.

20). -4 de julio de 1899, que declara en vigencia el art. 119 de la ley de $1^{\circ}$ de noviembre del879, (Ley de timbres).

21). -24 de julio de 1901 .

22). - 19 de enero de 1910. y

23). - 2 de abril de 1924, que establece que el impuesto grava el precio mismo de las enajenaciones, cualesquiera que sean las formas y condiciones en que se pague.

24). -8 de agosto de 1901, y

17 de junio de 1904, que exonera de impuesto las escrituras de división $y$ partición $y$ las ventas entre condóminos.

25). - 6 de febrero de 1902, sobre obligaciones de los notarios.

26). - 18 de febrero de 1903, que establece que las multas que se apliquen por infracción de las leyes sobre impuesto de alcabala o de registro, se dividirán en partes iguales entre la Recaudación y el denunciante.

27). - 29 de febrero de 1904 ,

28). - 16 de agosto de $1905, y$

29). - 28 de noviembre de 1923. que declara sin lugar la cobranza de alcabala por una compra-venta nula de ipso-jure.

30). - B de diciembre de 1905, sobre multa por falta de pago del impuesto.

31). -16 de mayo de 1906, y

32). - 15 de marzo de 1929, que exoneran de impuesto de entrega de bienes al acreedor para que los venda y dedique su precio a cancelar deudas.

33). -8 de agosto de 1906, que exonera de impuesto las escrituras de promesa de venta de inmuebles.

34). -16 de agosto de 1906, que dispone que, en las multas por falto de pago de impuesto, está incluido el valor del mismo.

35).-16 de agosto de 1906, que establece que, en caso de escrituras privadas o cutorizadas por los Jueces de Paz, en lugares donde no hay entidad recaudadora, el impuesto se cobrará sin recargo, en cualquier tiempo por el interesado se presente $\alpha$ pagarlo o que se les cobre.

36). -22 de abril de 1907, que establece que, las ventas sometidas a condición resolutoria deben pagar alcabala; pero que las escrituras de rescisión, originadas por el cumplimiento de la condición, no pagan alcabala. 
37). - 5 de octubre de 1908 .

38). - 3 de mayo de 1911, y

39).-20 de marzo de 1919, que declaran sin lugar la devolución de alcabala por una minuta que no llegó a elevarse a escritura pública.

40).-12 de mayo de 1912, que dispone que procede el cobro de alcabala, sobre la división de bienes, cuando los derechos de familia se reconocen por contratos entre las partes; porque ello no es participación de herencia, sino enajenación de bienes.

41). - 25 de agosto de 1909, que dispone que las compra ventas realizadas en ejercicio de un pacto de preferencia están sujetas a impuesto.

42). - 13 de octubre de 1909, que establece que, en las ventas en que no se discrimina la parte del precio que corresponde a muebles é inmuebles, la alcabala grava al precio total.

43). - 22 de diciembre de 1909, que establece que, la retroventa, ejercida después del término legal en que se permite, debe considerarse como una nueva venta afecta a la alcabala.

44). - 16 de febrero de 191C, según la que, en las ventas sujetas a condición suspensiva, no da lugar al pago de alcabala sino cumplida la condición.

45). - 25 de febrero de 1910, que establece que la alcabala no grava la parte del precio que el comprador ha pagado al arrendatario por las mejoras.

46). -31 de mayo de 1912, que establece que los contratos de compraventa de terrenos para la construcción de ferrocarril deben considerarse como expropiación forzosa.

47). - 16 de octubre de 1913, que dispone que la enajenación del dominio útil está afecta a alcabala sobre el precio estipulado.

48). - 5 de junio de 1914, que dispone que, en el caso de que no haya aplicación de multa por falta de pago de impuesto, total denunciante la tercera parte de la suma que se recauden.

49). - 11 de febrero de 1915, que declara inaplicable a la alcabala de enajenaciones la prescripción de tres años establecida por la ley $\mathrm{N}^{\circ} 256$.

50). - 10 de mayo de 1916, que exonera de impuesto las declaraciones sobre verdadero comprador que se hagan dentro de 24 horas de extendida la escritura de venta.

51). -21 de febrero de 1917, que declara no haber lugar a la devolución de alcabala cobrada por una compra-venta anulable, producida la anulación.

52). - 2 de enero de 1918, que establece que la redención de la enfiteúsis no paga alcabala de enajenaciones sino impuesto al registro.

53). -6 de marzo de 1918, que dispone que la transferencia de derechos reales litigiosos no está exenta de pago de impuesto

54). - 6 de octubre de 1920, que establece que no procede la exención de impuesto de alcabala, en la venta entre condóminos cuando sus derechos no han nacido del mismo título.

55). - 21 de mayo de 1924, que dispone que no procede el cobro del impuesto de la venta de terrenos, de precio no mayor de $S / .10,000.00$, siempre que sean pagados por mensualidades iguales.

56). - 13 de agosto de 1924, que exonera de impuesto las promesas 
de venta, pero no la venta de promesas de venta.

57). - 21 de abril de 1926, que dispone que la recaudación no dará pase a las escrituras de las compañías urbanizadoras, sobre ventas de terreno por mensualidades, sin el visto bueno de la Inspección Fiscal del Ramo.

58).-7 de mayo de 1926, que establece que para celebrar contratos sobre terrenos de irrigación, es necesario que estén aprobados los estudios respectivos por el Gobierno y que, antes de dicha aprobación no puede la Compañía Recaudadora de Impuestos (Caja de Depósitos y Consignaciones, Departamento de Recaudación) recibir el pago de alcabala.

59). - 20 de actubre de 1926, sobre precio sujeto a alcabala en la venta de inmuebles gravados con hipotecas.

60). -7 de abril de 1931, que declara sin lugar el pedido de derogatoria del art. $2^{\circ}$ de la ley 6809.

61). -5 de mayo de 1931, exonerando de impuesto los contratos de compra de terrenos efectuados por la Caja de Depósitos y Consignaciones.

62). - 4 de noviembre de 1931, que exonera la transferencia de un remclcador, adquirido por el Ministerio de Marina.

63). -24 de noviembre de 1931. que exonera de impuesto la rescisión de una compra-venta efectuada por mensualidades.

64). - 10 de junio de 1932, que establece que cuando el valor declarado en los contratos es evidentemente menor que el verdadero, que el Fisco puede rechazarlo para los efectos de la tributación.

65).-10 de febrero de 1933, que exonera de impuesto la donación de un inmueble de las religiones franciscanas de la Inmaculada Concepción.

66). - Il de agosto de 1933, establece que la multa procede cuando perfeccionada la venta no se paga el impuesto.

67). - 14 de octubre de 1933, que exonera de impuesto la compa-venta de terrenos a las religiosas franciscanas de Barranco.

63). - - g de diciembre de 1933, que exonera de impuesto la compraventa de terrenos por la Congregación San Vicente de Paul.

69).-14 de diciembre de 1933, en la ventas de lotes en Urbanizaciones del Estado, no están exoneradas del impuesto de alcabala.

70). - 25 deenero de 1934, exonerando de impuesto la adquisición de un terreno por el Municipio de Cajomarca.

71). -25 de enero de 1934, las declaraciones de verdadero comprador, dentro de las veinticuatro horas no están afectas al impuesto.

72). - 28 de agosto de 1934, exonerando de impuesto al Asilo que regentan las Hermanitas de la Asunción.

73). - 19 de octubre de 1934, las permutas con terrenos municipales están exonerados del impuesto.

74). - 24 de octubre de 1934. Ias adjudicaciones de terrenos a los municipios estón exonerados de impuestos.

75). - 18 de diciembre de 1934, tratándose de transferencias, de promesas o de opción sobre concesiones petroleras, la Caja de Depósitos y Consignaciones, Departamento de Recaudación, no dará pase de pago o exoneración de impuesto, si previamente no es visada la minuta por la Dirección de Industria Minera y Fabril.

76). -4 de junio de 1935, tratándose de la adquisición de terrenos para taller de obreras, no procede la exoneración. (Misioneras franciscanas). 
77).-22 de octubre de 1935, las adquisiciones de terrenos que realice el Estado, estón exonerados de impuesto.

78).-18, de mayo de 1936, exonerado de impuesto las casas obsequiadas por el Concejo Provincial de Lima, con motivo del IV Centenario de la fundación de Lima.

79). - 31 de julio de 1936, que exonera de alcabala las adquisiciones que hagan las Minicipalidades de inmuebles destinados a obras públicas.

80). - 31 de agosto de 1936, exonerando de impuesto la donación de terreno hecha al Club de la Unión, para que construya su sede social.

81). - 15 de julio de 1938. Ia transferencia entre condóminos como consecuencia de la división y partición, estón exonerados de impuesto.

82). - 25 de enero de 1940. las adjudicaciones hechas por el Estado, estún exonerados cle impuesto.

83). -6 de marzo de 1940, que exonera de alcabala la compra-venta de inmuebles por los organismos construidos por el Poder Ejecutivo para determinados fines sociales.

84).-13 de marzo de 1940. exonerando la adquisición de inmueble por parte del Cuerpo Diplomático.

85). - 26 de mazzo de 1940, que prescribe que los funcionarios encargados de dar "pase" a las minutas de escritura pública no podrán negarlo For razón de deuda de impuesto distintos de la alcabala.

86). - I7 cie cbrill de 1940, exonerando de impuesto de permuta de terrenos municipales, para obras públicas.

87). - 21 de mayo de 1941. exonerando del $2 \%$ de impuesto de construcción de cbras de beneficio municipal.

88). -23 de diciembre de 1941, exonerando de impuesto de alcabala, la doncción de terreno hecha $\alpha$ una iglesia parroquial.

89). - II de abrì de 1942, procede la devolución del impuesto cuando la escritura pública adolece de nulidad absoluta.

90). -19 de mayo de 1942. exonerando la compra de terreno para la construcción de la Escuela Central de Reserva Aérea.

91). - Il ce agosto de 1942, exonerando de impuesto las permutas de terrenos del Obispado.

92). - 11 de agosto de 1942. que exonera de alcabala la venta de los lotes que resulten en casos de expropiación forzosa.

93). 30 de cctubre de 1942, que fija el procedimiento a seguir en los casos en que se concede exoneración de impuesto.

94). -19 de noviembre de 1942, que establece medidas de controlar parc la acotación y recaudación de la alcabala de enajenaciones.

95).-31 de diciembre de 1942. oue dispone que las modificaciones de minutas de escrituras públicas introducidas antes de ser suscritas por los otorgantes, para después de presentarse a la Recaudación, deben ser visadas por ésta.

96). -7 de noviembre de 1942. exonerando de impuesto de alcabala las adquisiciones hechas por el Estado.

97). - 30 de abril de 1943, exonerando del impuesto de alcabala las adquisiciones efectuadas por los Municipios.

98). - 25 de junio de 1943. exonerando de impuesto de alcabala, la cesión de terrenos municipales. 
99). -4 de julio de 1945, exonerando la adquisición de terrenos por parte de las Embajadas Extranjeras.

100). - 25 de octubre de 1945, las Comunidades Indígenas, se encuentran exoneradas de impuesto, por estar sujetas a un régimen especial de protección por parte del Estado.

101).-21 de junio de 1946, exonerando la adquisición de una finca por parte del embajador de Colombia.

102). -23 de junio de 1946, exonerando el $50 \%$ de la alcabala la venta de un inmueble de la obra Pia Luisa de Marillac.

103).-14 de enero de 1946, exonerando de impuesto de alcabala la compra de una finca por la Institución Hijas de María Inmaculada.

104). - I4 de febrero de 1946, exonerando de alcabala la compra de un terreno por el Convento de Santo Domingo.

105). -7 de tebrero de 1947. exonera a los terrenos que se cedan al Estado por las Cías. Urbanizadoras.

106). - 14 de febrero de 1947, exonera a los terrenos adquiridos por las Cías de Bomberos.

107). - 25 de agosto de 1947, exonerando de alccbala la adquisición de un inmueble por el Instituto Hijas de María.

108). -22 de febrero de 1948, exonerando de impuesto las adquisiciones hechas por el Estado.

109). - 30 de abril de 1948. las cooperativas de Vivienda, no gozan de exoneración de alcabala.

110). - 15 de mayo de 1950, exonerando de alcabala el terreno adquirido por la Sociedad de María (Marianistas).

111). -6 de junio de 1950, exonerando de alcabala la adquisición de un terreno a la Congregación de Siervas de María, para la construcción de su convento.

112). -8 de marzo de 1951. exonerando de alcabala la compra de un inmueble por la Asociación Marítima de Tripulantes.

113). -29 de enero de 1952, exonerando de alcabala la adquisición de terrenos por los trabajadores en autobuses Línea 22 en la Urbanización Ciudad y Campo.

114). - 13 de diciembre de 1952, declara exonerado de impuesto de alcabala, el contrato de venta entre el Seminario de Sto. Toribio y J. Fonseca.

115). - 15 de diciembre de 1952, exonerando de alcabala de enajenaciones en favor de un inmueble destinado a hotel.

116). - 22 de diciembre de 1952 .

117). - 12 de marzo de 1954, exonerando de alcabala el contrato de concesión de tierras de montaña a la Corporación "Le Tourneau del Perú Inc."

118). - 16 de marzo de 1954. exonerando en un $50 \%$ del impuesto de alcabala la concesión de tierras de montaña para colonización a "Anderson Clayton \& Cía." S. A.

119). -7 de setiembre de 1954, declarando que no procede la exoneración de álcabala, en las permutas de terrenos cuando la redistribución de dichos terrenos ha sido aprobada por Resolución Ministerial.

120). -11 de abril de 1955, exonerando de alcabala las permutas de 
terrenos transferidos por el Estado.

121). -22 de abril de 1955, exonerando de alcabala la compra de un inmueble por el Correo de la ciudad de Tarma.

122). -17 de octubre de 1956, exonerando de impuesto de alcabala la compra de un avión a Panagra.

123). -2 de tebrero de 1957, exonera la compra-venta que adquiere la Universidad Católica del Perú (Ley Orgánica de Educación).

124). - 27 de febrero de 1957. No 34. declara que la Corporación Nacional de Alimentos está exenta de impuestos.

125). - 19 de febrero de 1957.

126). - 8 de junio de 1957, exonerando el contrato de los Padres Lazaristas con la Sra. Ferreyros.

127). - 8 de junio de 1957. que exonera el contrato de la Cía. Camercial Importadora con la Cía. de Bomberos.

128).-21 de junio de 1957, que exonera el contrato del Sr. Mujica con siervas del Inmaculado Corazón de María.

129). -14 de octubre de 1957, exonerando la compra de terrenos por el Instituto de Hijas de Maria Inmaculada.

130). -16 de noviembre de 1957, exonera la venta de inmueble al Instituto Cultural Peruano-Norteamericano.

131). - de noviembre de 1960 , exonerando de impuesto de alcabala la adjudicación de tierras para irrigación a la Cía. Irrigadora Chimbote S. $\bar{A}$.

132). -6 de mayo de 1959, exonerando de impuesto los contratos de la Junta de Rehabilitación y Desarrollo de Arequipa.

133). - 17 de noviembre de 1961, No 59, exonerando de impuesto al Instituto de la Vivienda.

134. -6 de abril de 1962, exonerando de impuesto de alcabala al Servicio Especial de Salud Pública (SESP).

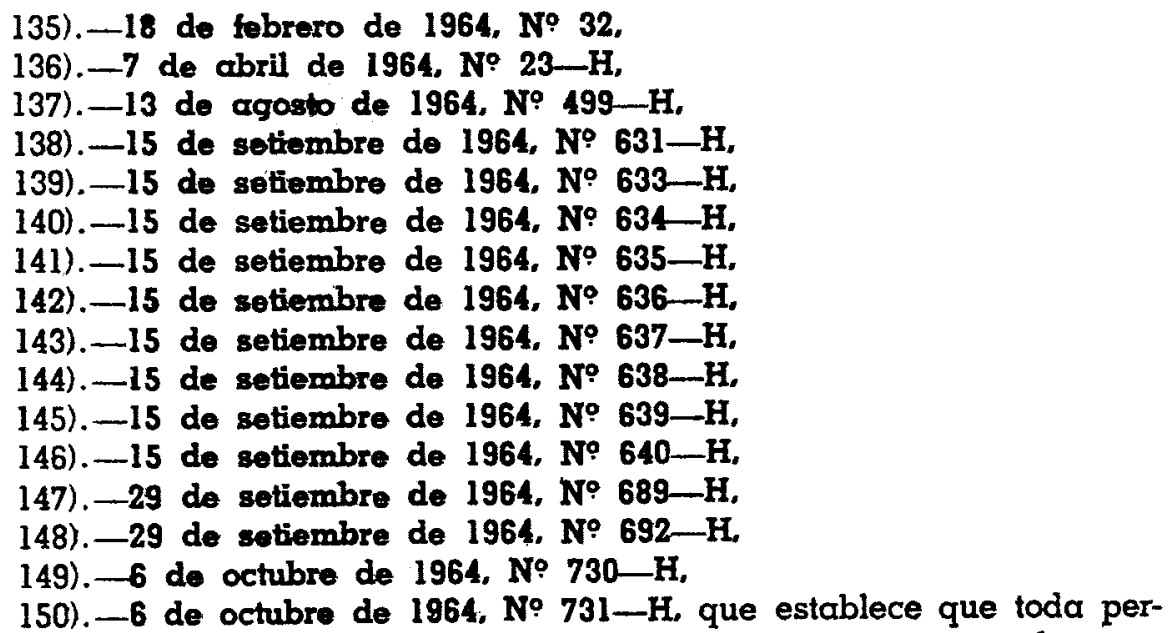
sona natural o jurídica, que incida en la industria y comercio en la zona selva, está exonerada de todo impuesto, de conformidad con los Decretos Supremos Nos. 4 y 10 de enero, 23-H de 3 de abril de 1964, y el Regla- 
mento de ambos de 11 de mayo del mismo año, sobre desgravación tributaria en la Selva, al amparo de la ley No 9140.

151). - 7 de abril de 1964. No 4-H, exonera de impuesto de alcabala, al Fondo de Empleados de la Caja de Depósitos y Consignaciones, Departamento de Recaudación, que adquieran viviendas de tipo económico.

152). -7 de abril de 1964, No 3-H, exonerando a las viviendas que adquieran el personal del Banco Central de Reserva del Perú.

153). -28 de agosto de 1964, No 520-H, las prestaciones para fines de vivienda quedan comprendidas en las exoneraciones de la ley $N^{0} 13500$.

154). - 29 de setiembre de 1964 , $\mathrm{N}^{\circ}$ 686-H, señalando los requisitos para solicitar exoneraciones tributarias en la zona de la selva.

155). - 28 de diciembre de 1965, No 1400-H, exonera a los contratos de compra-venta de inmuebles construídos por el Fondo de Jubilación Obrera

\section{N).-RESOLUCIONES MINISTERLALES.-}

1). -28 de octubre de 1935. la adjudicación en pago como resultado de una ejecución, está exonerada de impuesto de alcabala.

2).-4 de marzo de 1936, declarando que el contrato de compra-venta, celebrado por la Comunidad Religiosa de la Salle con Ramón Aspillaga está afecta al pago de alcabala.

3).-27 de agosto de 1937, declarando que la compra de un terreno, efectuada por el Colegio de Villa María Academy de Miraflores, está afecta al pago de alcabala.

4). -2 de abril de 1938, $y$

5).-12 de abiil de 1938, declarando que las donaciones hechas a favor de la Arquidiócesis de Lima, para la construcción de Seminario de Sto. Toribio, para la formación del Clero Nacional, están exoneradas del pago de alcabala.

6).-13 de mayo de 1940, que exonera de alcabala la adquisición por gobierno extranjeros de inmuebles destinados a residencia oficial.

7). - 10 de mayo de 1941, exonerado de alcabala la donación celebrada entre el Concejo Provincial de Marañón y el Supremo Gobierno.

8). - 8 de agosto de 1941, que dispone que no procede la devolución de alcabala, en los contratos cuya minuta ha sido firmada.

9).- II de abril de 1942, que establece que no procede el cobro de alcabala de enajenaciones sobre contratos nulos ipso-jure.

10). - 27 de enero de 1954, declarando que la escritura de compraventa por la que el Colegio Seminario de Huancayo adquiere un inmueble, para destinarlo a la construcción de un local para colegio está afecto al pagio de alcabala.

11). -27 de febrero de 1954. declarando que el contrato de compraventa celebrado por la "Asociación Unión Hijos del barrio de la Āsunción" con Lorenzo Villafana, está afecto al pago de alcabala.

\section{O).-RESOLUCIONES DIRECTORAIES.-}

1). -2 de febrero de 1939, declarando que las mejoras de herencia están afectas al pago de alcabala. 


\section{P).-RESOLUCIONES DEL CONSEJO SUPERIOR DE CONTRIBUCIONES. -}

1).--RCSC. de 1 de enero de 1939, que exonera de alcabala el mayor precio de venta; respecto al vaior de tasación, obtenido en la venta de derechos hereditarios entre condóminos.

2).-RCSC. del 4 de marzo de 1939, sobre requisitos para que las transacciones de dominio entre condóminos estén exentas de pago de alcabaia.

3). - RCSC. de 12 de noviembre de 1941, que establece que, en los. casos de rifas, el impuesto grava el valor del inmueble rifado.

4).--RCSC. de 5 de setiembre de 1942. los contratos de traslación de dominio de inmuebles a capítulo de igualación están afectos al pago de alcabala.

5).--RCSC. de 10 de julio de 1942, no procede el cobro de alcabala si se prueba que la venta no se llevó a cabo aunque se firme la minuta.

6).-RCSC. No 5444, de 15 de noviembre de 1949 , la adjudicación de un bien propio de un cónyuge $\alpha$ otro en pago de los gananciales, practicado no en vía de división y partición, está áfecta al pago de alcabala.

7). - RCSC. No 5462, de 22 de noviembre de 1949, las exoneraciones de impuesto sólo son díctadas por el Gobierno. Sólo pueden interpretarse restrictivamente y no por analogía.

8).-RCSC. No 5478 , de 29 de noviembre de 1949.

9).-RCSC. No 88C9, de 28 de febrero de 1958 ,

' 10). - ECSC. No 9173, de 5 de agosto de 1958, las rescisiones de ventas de inmuebles, se consideran como nuevas ventas, sujetas al pago de alcabala, quedando como bien pagados los que se hicieron por el acto rescindido.

11).--RCSC. No 5193, de 3 de mayo de 1949, el retrocto ejercitando por un condómino procede la devolución de la alcabala que abonó el comprador inicial.

12).--RCSC. No 5849, de 3 de octubre de 1950, los aportes de inmuebles hipotecados, para formar capital de sociedades, no están afectos al impuesto de alcabala.

13).-RCSC. No 7263, de 20 de julio de 1954, en las ventas de acciones y derechos, sólo procede la exoneración a los condóminos nacidos en un mismo acto.

14).--RCSC. No 7739, de 26 de agosto de 1955, el impuesto de alcabala de enajenaciones percibe $\alpha$ los 15 años de la fecha de la escritura pública.

15).-PCSC. No 7750, de 13 de setiembre de 1955, declara que si el comprador no firma la escritura pública de venta no hay traslación de dominio y no procede el cobro del impuesto.

16).-RCSC. No 7764, de 23 de setiembre de 1955, establece que en el caso de inmuebles rifados el impuesto se aplica sobre el valor de inmueble y sobre el valor de los boletos en rifa.

17). - RCSC. No 8155, de 7 de agosto de 1956, en caso de aportes en inmuebles hipotecados, lo que el aportador recibe en efectivo para cancelor la obligación está afecta al impuesto de alcabala. 
18).-RCSC. No 8334, de 28 de diciembre de 1956, cuando se rescinde el contrato de compra-venta no procede el cobro del impuesto de alcabala.

19).-RCSC. No 8632, de 13 de setiembre de 1957. Y

20).-RCSC. No 2388, de 20 de noviembre de 1944, la compra-venta en condóminos no originarios está afecta al pago del impuesto de alcabala (ver Nơ 2) pág. 55).

21). -RCSC. No 8837, de 14 de marzo de 1958, las transferencias de inmuebles que hagan los socios, vencido el plazo de la sociedad, están gravadas con alcabala de enajenaciones por considerarse disuelta la sociedad desde la fecha del citado vencimiento.

22).-RCSC. No 9096, de 1 de julio de 1958, la rescisión por falta de pago implica nueva transferencia por lo tanto no procede la devolución de alcabala.

23). -RCSC. No 9226, de 26 de agosto de 1958, en caso de no suscribir escriturd pública y hay certificación notarial que no corre la escritura, procede la devolución del impuesto.

24).-RCSC. No 9329, de 14 de octubre de 1958, la rescisión voluntaria no origina la devolución del impuesto.

25).-RCSC. No 9778. de 16 de junio de 1959, la compra-venta de parcelas para su independización están sujetas al pago de alcabala.

26).-RCSC. No 9936, de 25 de setiembre de 1959, la compra-venta de inmuebles para menores, están sujetas al pago de alcabala.

27). -RCSC. No 10142, de 19 de enero de 1960, de las acciones de nulidad en la compra-venta, no procede la devolución de la alcabala de enajenaciones por tratarse de una resolución voluntaria.

28). -RCSC. de 1 de mazo de 1960. la adjudiçación de un inmueble en devolución del capital por disolución de la sociedad o reducción del capital, no están afectas a impuesto, conforme $\alpha$ los arts. $7^{\circ}, 8^{\circ}$ y $12^{\circ}$ de la ley de 23 de enero de 1896.

29). - RCSC. No 10459. de 23 de setiembre de 1960, y

30).-RCSC. No 5488, de 16 de diciembre de 1949, la transferencia de dominio de embarcaciones destinadas a la navegación de cabotaje o altura están afectas al pago de alcabala.

31).-RCSC. No 10481, de 14 de octubre de 1960, las rescisiones de ventas de inmuebles por falta de pago, no procede la devolución. El contrato se perfeccionó desde que se conviene en la cosa y en el precio. (ver $\mathrm{N}^{\circ}$ 22 de la pág. 56).

32).-RCSC. No 10526, de 18 de noviembre de 1960, las escrituras de compra-venta celebradas por las Empresas Eléctricas Asociadas, de inmuebles $y$ que afecten directamente sus ingresos estarán gravadas con la tasa del $2 \%$ de alcabala de enajenaciones de conformidad con la ley 4510 .

33).-RCSC. No 10543. de 29 de noviembre de 1960, las declaraciones de verdadero comprador hechas después de 24 horas de celebrada la escritura de compra, pagan alcabala de enajenaciones, con nueva venta.

34).-RCSC. No 10851, de 14 de noviembre de 1961, declaran que las compañias de Bomberos no están exonerados por la ley.

35). -RCSC. No 11157, de 14 de setiembre de 1962, falta de pago previo $\mathrm{y}$ rescisión no origina la devolución del impuesto. 
36).-RCSC. № 11366, de 5 de julio de 1963, gravando la transferencia de la posesión.

\section{RESOLUCION TRIB. FISCAL}

1) Res. T. Fis. 281 - 14 mayo 1964. - No procede exoneración tributaria con posterioridad al hecho que originó impuesto. Leyes tributarias no pueden aplicarse por analogía.

2) Res. T. Fis. $389-2$ Junio 1964. - Tribunal no puede exonerar pago Impuesto.

3) Res. Trib. Fis. 396 - 3 Junio 1964. - Cuando no se pacta quién debe pagar el impuesto, se aplica art. 1390 C. C. $(5 \%$ cada contratante)

4) Resolución Tribunal Fiscal No 1,000 de 9 de Noviembre de 1964.La transferencia de inmuebles ocasionada por la disolución de una sociedad está afecta con el impuesto de alcabala sobre los valores que excedan del capital social que se liquida.

\section{R).-CONSULTAS:}

1).-Consulta $\alpha$ la Superintendencia de Contribuciones de 19 de julio de 1963. solicitada por la Cámara Peruana de Construcción.-exonera los contratos de compra de terrenos por Sociedades Constructoras, de acuerdo $\alpha$ Decreto Supremo No 46 de $1^{\text {o }}$ de junio de 1962, para dedicarlo a la construcción de viviendas populares de tipo " $\mathrm{A}$ " y " $\mathrm{B}$ ".

2). Consulta a la Junta Nacional de la Vivienda, de 3 de junio de 1963. solicitada por el Estudio Belaúnde Guinassi, requisitos para que funcione las exoneraciones de la ley $N^{\circ} 12370$ y Decretos Supremos $N^{\circ} 46$ de $1^{\circ}$ de junio de 1962, 6 y 27 de octubre de 1961.

2.-De los impuestos especiales:

1.-Del impuesto a las tronsferencias de concesiones de explotación de petróleo.-

A. - Leyes:

a.-Ley 4452, de 2 de enero de 1922 (art. 39) que crea el impuesto. con una tasa del $5 \%$.

Nota.-A tenor del art. $135^{\circ}$ de la ley 11780 , la aplicación de esta ley puede ser solicitada por los concesionarios, cuya concesión es nacida antes de la promulgación de la Ley Orgánica del Petróleo (12.3.52).

b.-Ley 11780 de 12 de marzo de 1952 (art. 102) que crea el impuesto adicional de $5 \%$ sobre el precio pactado o sobre el valor fijado por peritos, si la cesión fuese gratuita.

2.-Del impuesto a la transferencia administrativa de lotes no pagados totalmente en las urbanizaciones del Estado.- 


\section{A.-Disposiciones reglamentarias:}

a.-Resoluciones Supremas de 14 de diciembre de 1933 y 10 de febrero de 1940, que crean el impuesto, con una tasa del $5 \%$.

3.-Del impuesto a la transferencia de concesiones de terrenos eria200 del Estado para irrigarlos.

\section{A.-Disposiciones reglomentorias.}

a.-Decreto Supremo de 22 de abril de 1922, que crea el impuesto con una tasa de S|. 1.00 por hectórea transferida.

4.-Del impuesto a la transferencia de concesiones de aprovechamientos de aguas para la producción de tuerza motriz:

\section{A.-Disposiciones reglamentarias:}

a.-Decreto Supremo de 22 de abril de 1922, que crea el impuesto con una tasa de S|. 1.00 por caballo de fuerza motriz.

5. - En transierencias bienes muebles aceres o derechos sobre estos, autos orts. vitalicias (art. $2^{\circ}$ Ley 15225, 23 Nov. 1964) aportes muebles Someases.

\section{IV.-ADMINISTRACION:} impuesto:

1. - Organización de las reparticiones acotadoras y recaudadoras del

1.-Del impuesto General:

A. - En el Perú:

Acotación: Superintendencia Nacional de Contribuciones mediante:

a).-Departamento de Transferencia de Bienes a Título Oneroso, donde se practica la liquidación del impuesto. (ver formulario adjunto).

b).-Departamento de Revisión (Segundo Departamento), revisan la liquidación y dan su conformidad.

Recaudación: Caja de Depósitos y Consignaciones, Departamento de Recaudación, es la entidad que recibe el pago del impuesto, mediante recibo numerado.

\section{B. - En el Extrcrnjero:}

Los agentes diplomáticos y consulares del Perú que extiendan escrituras públicas de actos, sujetos a alcabala de enajenaciones.

2.-De los impuestos especiales:

A.-Del impuesto a la transferencia de concesiones de explotación de petróleo.

Acotación: Ministerio de Fomento y Obras Públicas, mediante, la Dirección de Petróleo, donde se practica la liquidación.

Reccudación: Caja de Depósitos y Consignaciones. 
B.-Del impuesto a la transferencia administrativa de lotes no pagados totalmente en las urbanizciones del Estado.

Acotación: Ministerio de Fomento y Obras Públicas, mediante, el Departamento de Urbanizaciones, donde se practica la liquidación.

Recaudación: Caja de Depósitos y Consignaciones.

C.-Del impuesto a las transferencias de concesiones de terrenos eriazos para irrigarlos.

Acotación: Ministerio de Agricultura, mediante la Dirección de Aguas e Irrigación, donde se practica la liquidación.

Recaudación: Caja de Depósitos y Consignaciones.

D. -Del impuesto a la transferencia de concesiones de aprovechamiento de aguas, para producción de fuerza motriz.

Acotación: Ministerio de Agricultura, mediante la Dirección de Aguas e Irrigación, donde se practica la liquidación.

Recaudación: Caja de Depósitos y Consignaciones.

$2^{\circ}$ - - Competencia:

La oficina del lugar en que se realice el contrato.

30.-Reclamaciones administrativas:

Ante la Superintendencia Nacional de Contribuciones.

Ante el Tribunal Fiscal.

4․-Contratos celebrados por el Estado, exonerados del impuesto:

Entidad informante: La Sucerintendencia Nacional de Contribuciones (D.S. de 15 de setiembre de 1942).

\section{V.-EI CONTRIBUYENTE:}

1.-Personas obligadas al pago:

1.- Todo aquel que transfiere o adquiere un inmueble (arts. 1391 y 812 del CC.), una acción o derecho sobre un inmueble, (art. $1^{\circ}$ de las leyes 4381 y 6809) pcries apartes adjudicaciones de las mismas, Ley 15225.

2. - Todo aquel que intervenga como parte en la celebración de un contrato de jenta vitalicia, art. $3^{\circ}$ de la ley 6909).

3.-.-ioto aquel que intervenga como parte en la celebración de un contrato de usufructo, (art. $1^{\circ}$ de la ley 4881).

4.-Todo el que intervenga en transp. bienes o derecho sobre muebles, autos, etc. (Ley 15225).

\section{2.-Personas exceptuadas:}

1.-El Estado, en los contratos en que intervenga, si ello se hace constar expresamente, (R.S. de 25 de abril de 1892).

2.- Los Gobiernos extranjeros, cuando adquieren inmuebles destinados a residencia oficial, (R.M. de 13 de marzo de 1940).

3.-Las Municipalidades, cuando adquieren inmuebles destinados a obras públicas, (R.S. de 31 de julio de 1936). 
4.-Las Sociedades de Beneficencia Pública, en las transferencias onerosas de inmuebles en que intervengan, (ant. $1^{\text {o }}$ de la ley 6051 y art. $27^{\circ}$ de la ley 8128 ).

5. - La Caja Nacional del S=guro Social, en las transferencias onerosas de inmuebles en que intervengan, (inc. a del art. $67^{\circ}$ de la ley 8433).

6. - Los organismos constitúdos por el Poder Ejecutivo para determinados fines sociales, en las adquisiciones de inmuebles que verifiquen, ( $R$. S. de 6 de marzo de 1940).

7.-Los condóminos, por las escrituras de división y partición y las ventas que celebren entre sí, siempre que sus derechos hayan nacido del mismo título comprendiéndose en la excepción el caso de que algún copropietario haya trasmitido su derecho por herencia o legado, (inc. c del art. 1 \% de la ley 6809; R. S. de 19 de octubre de $1872 ;$ R. S. de 8 de agosto de 1901; R. S. de 17 de junio de 1904; y RCSC. de $1^{\circ}$ de marzo de 1939).

8. - Los coherederos, por las ventas que efectúen entre sí, así no sean condóminos, (R. S. de 15 de julio de 1889).

9.-Las Universidades, en las transferencias onerosas de inmuebles en que intervengan, (art. $77^{\circ}$ de la ley 13417).

10. - Los Museos, en las transferencias onerosas de terrenos y edificios, que tengan como destino la constitución de un museo, (art. $9^{\circ}$ de la ley 12956).

11.-Las Corporaciones creadas con capital aportado por el Estado. (D.S. de 19 de julio de 1945).

12.-Las Compañías Nacionales de Transporte Aéreo, las adquisiciones que efectúen con aval i/o fianza del Estado, art. 59 de la ley 13514).

13. - Las Cooperativas de Viviendas, al amparo de la: Ley 12813. (D. S. de 3 de noviembre de 1961). Ley 15260, 14 Dic. 1564(66), inc.e.

14.-Las Compañías de Bomberos, en las adquisiciones de inmuebles, para sus instituciones, (art. único de la ley 14055).

15. -Las Empresas que se dediquen a la construcción de viviendas, en las adquisiciones, que efectúen para aquellos fines, (D.S. de 27 de enero de 1961).

16. -Las Empresas Nacionales de Ferrocarriles, en las adquisiciones para sus actividades, (D.S. de 18 de junio de 1962).

17).-Las Comunidades Indígenas, en las adquisiciones en que intervengan como parte, (R.S. de 25 de octubre de 1945).

18.-El Servicio Nacional de Aprendizaje y Trabajo Industrial SENATI, en las donaciones que reciba para sus fines, (art. $17^{\circ}$ de la ley 13771).

19. -El Ministerio de Educación, en las donaciones de inmuebles para locales escolares, (art. $1^{\circ}$ de la ley 14413).

20. -La Empresa Petrolera Fiscal, en las adquisiciones de inmuebles para sus fines, (art. 16\% del Decreto-Ley 14473).

21.-Los Clubs Departamentales, en las adquisiciones de inmuebles para sus sedes sociales, (art. único de la ley 14034; art. único de la ley 14510; art de la ley 14512; art. de la ley 14513).

22. - Los Establecimientos Penales y de Tutela, en las donaciones que reciba, (art. $1^{\circ}$ de la ley 14771).

23). - Ia Biblioteca Nacional, en las donaciones que reciba, (art. $1^{\text {a }}$ de la ley 14602). 
El vaior por el que se hace la transferencia

(No está legible el manuscrito... gracias)

24). - Las personas naturales o jurídicas que se dediquen a la industria o comercio en la zona selva. (D.S. No $4^{\circ}$ de 10 de enero de 1964, D.S. No 23-H del 3 de abril de 1964 y D.S. No 11 de mayo de 1964).

18.-Las operaciones de adquisiciones para efectuar lá reforma agraria (art. 58 de la ley 15035).

\section{VI.-LA MATERLA IMPONIBLE:}

\section{1.-Actos afectos a impuestos:}

1.-La compra-ventas de inmuebles, aportes $y$ adjudicaciones (art.. $1^{\circ}$ de la ley 4881) (Ley 15225).

2.-El acto por el cual se instituye el usufructo, (art. $1^{\text {o }}$ de la ley 4881 ).

3.-Las permutas de inmuebles, art. $1^{\text {o }}$ de la ley 4881).

4.-La cesiones de inmuebles en pagos de deudas (Ri.S. de 24 de octubre de 1889).

5.-Los actos por los cuales se constituye una renta vitalicia, art) $3^{\circ}$ de la ley 6809).

6.-Las ventas enfiteúticas, (R.S. de 21 de junio de 1865); y R. S. de 16 de octubre de 1913).

7.-Las ventas de inmuebles situados en la fepública, celebradas en el extranjero, R.S. de 17 de octubre de 1889).

8.-Las ventas celebradas bajo condición resolutoria (R.S. de 22 de abril de 1907).

9.-Las rescisiones de contratos de compra-venta de inmuebles ( $R$. S. de 5 de enero de 1888 , R.S. de 18 de julio de 1906, R.S. de 18 de octubre de 1909 y R.S. de 18 de setiembre de 1919).

10.-Las compra-ventas anulables aunque se produzca la anulación, (R.S. de 21 de febrero de 1917).

11.-Los contratos de compra-venta de inmuebles, aunque la minuta no se eleve a escritura pública. (R.S. de 5 de octubre de 1908; R.S. de' 3 de mayo de 1911; R.S. de 20 de marzo de 1919 y R.M. de 8 de agosto de 1941). 1890).

12.-Las ventas con pacto de retroventa, (R. S. de 10 de julio de

13. - Los actos de retroventa ejercidos después del término legal، ( $R$. S. de 22 de diciembre de 1909).

14). - Las compra-ventas realizadas en ejercicio de un pacto de preferencia, (R.S. de 15 de agosto de 1909).

15. -Las ventas de promesas de venta, (R. S. de 13 de agosto de 1923).

16.-El pago que hagan el marido o sus coherederos de los bienes propios de la mujer, de que áquel ha dispuesto, (R.S. de 12 de julio de 1888).

17. -Las ventas que los coherederos hagan a personas extrañas a la herencia, (R. S. de 19 de noviembre de 1853).

18. - Las ventas entre condóminos cuando sus derechos no han na. cido del mismo título, (R.S. de 6 de octubre de 1920 y RCSC. de $1^{\circ}$ de: marzo de 1939). 
19. - Las divisiones de bienes, cuando los derechos de familia se reconocen por contratos entre las partes, porque ello no es partición de herencia sino enajenación de bienes, (R.S. de 12 de mayo de 1909).

20). - Las transferencias de derechos reales $Y$ litigiosos, (R.S. de 6 de marzo de 1918).

21. - Los actos por los cuales se establece a título oneroso una servidumbre, (art. $1^{\circ}$ de la ley 4881 ).

22. - Las transferencias de concesiones de explotación de petróleo, (art. 102 de la ley 11780).

23. - Las transferencias administrativas de lotes en la urbanizaciones del Estado, una vez que sea abonado el valor total, (R.S. de 14 de diciembre de 1933 y R.S. de 10 de febrero de 1940).

24.-Declaración verdadero comprador (Ley 15225).

\section{2․-Actcs exceptuados de impuestos:}

1.-Los de expropiación forzosa, (inc. b del art. 19 de la ley 6809). Dentro de éstos deben considerarse los contratos de compra-venta de terrenos para la construcción de ferrocarriles, (R.S. de 31 de mayo de 1912).

2. - La venta de lotes que resulten excedentes en caso de expropiación forzosc, (R.S. de 11 de agosto de 1942).

3. - Los actos de división y partición, (inc. c del art. 19 de la ley 6809 y R.S. de 21 de noviembre de 1853). Agregar las ventas entre condó. minos cuando sus derechos nacen del mismo título.

4.-Las ventas por mensualidades, de inmuebles urbanos destinados a hogar propia o de inmuebles rústicos cultivados por el comprador, su cónyuge o sus hijos, siempre que su precio no exceda de $\mathbf{S} / .10,000.00$, (art. $7^{\circ}$ y $10^{\circ}$ de la ley de 14 de noviembre de 1900 y R.S. de 21 de mayo de 1921).

5. - Las ventas de casas para empleados y obreros, (arls. $13^{\circ}$ y $14^{\circ}$ de la ley 6619).

6.-Las ventas de terrenos o de inmuebles que tienen por objeto la construcción o establecimientos de hoteles, (inc. $d$ del art. $3^{\circ}$ de la ley 8708).

7. -Las ventas que se hagan en la república, de inmuebles situados en el extranjero, (R.S. de 17 de julio de 1863).

8. - Las ventas celebradas bajo condición suspensiva, mientras está pendiente la condición, (R.S. de 16 de febrero de 1910).

9. - Las rescisiones de contratos de compra-venta de inm'lebles, en virtud de una condición resolutoria contenida en el pacto, (R.S. de 22 de abril de 1907).

10. -Las compra-ventas nulas de ipso-jure, (R.S. de 29 de febrero de 1904; R.S. de 16 de agosto de 1905; R.S. de 28 de noviembre de 1923 y R.M. de 11 de abril de 1942).

11. -Las compra-ventas en las que no se realiza el hecho económico de la transferencia aunque se haya firmado la respectiva minuta de escritura pública, (RCSC. de 10 de julio de 1942).

12. - Los actos de retroventa ejercidos dentro del término legal, ( $R$. S. de 10 de julio de 1890 y R.S. de 22 de diciembre de 1909). 
13. - Los actos de ejecución de un derecho de retracto, (RS. de 6 de setiembre de 1890; R.S. de 3 de febrero de 1909 y R.S. de 12 de enero de 1916).

14. - Las escrituras de promesa de venta de inmuebles, (R.S. de 8 de agosto de 1906).

15. - Los actos de declaración sobre verdadero comprador, que se hagan dentro de las 24 horas de extendida la escritura de venta, (R.S. de 10 de mayo de 1916). Ley 15225.

16. - La entrega de bienes al acreedor para que los venda por cuenta del deudor y dedique su precio a cancelar deudas, (R.S. de 16 de mayo y R.S. de 15 de marzo de 1929).

17. - La redención de enfiteúsis por esiar afecta a impuesto de registro, (R.S. de 2 de enero de 1918).

$3^{\circ}$. - Valor sujeto a impuesto:

1.-Regla general: está sujeto a impuesto el valor expresado en los contratos de traslación de dominio de inmuebles, de acciones o de derechos sobre inmuebles, (art. $1^{\circ}$ de la ley 4881 ).

\section{2.-Reglas especiales:}

A.-En la compra-venta en general: está sujeto a impuesto el precio total de la cosa, cualquiera que sean las formas y condiciones en que se paque, (R.S. de 24 de julio de 1901; R.S. de 19 do enero de 1910 y R.S. de 2 de abril de 1924).

B. - En las ventas en que no se discrimina la parte del precio que corresponde a inmuebles y la que corresponde a muebles: el valor expresado como precio total, (R.S. de 13 de octubre de 1909).

C - En la venta de derechos hereditarios entre condóminos: el valor de tasación, así el precio de venta sea mayor, (RCSC. de $1^{\circ}$ de enero de 1939).

D. - En la permuta: el valor total de los inmuebles que se transfieren, (art. $1^{\circ}$ de la ley 4881 ).

E.-En los casos de rifas: el valor del inmueble rif́ado, (RCSC. de 12 de noviembre de 1941).

F. - En las ventas enfitéuticas: el valor que resulta de multiplicar por diez el canon estipulado (R.S. de 21 de junio de 1865 y R.S. de 16 de octubre de 1913).

G.-En los casos en que se constituye una renta vitalicia: el valor que resulta de multiplicar por diez la renta constituída, (art. $3^{\circ}$ de la ley 6809).

H. - En los casos en que se constituye un usufructo: el valor que resulta de la aplicación de tablas especiales.

\section{VII. -DETERMINACION DE LA MATERIA IMPONIBLE:}

\section{1.--Procedimiento:}

Para la acotación de los impuestos que gravan los actos y contratos celebrados por escritura pública los interesados (contribuyentes) o el Nota- 
rio formularán declaración en los formularios ad hoc que proporcionarán la Superintendencia Nacional de Contribuciones (Leyes 5004 art. 1\%: 15225, art. 8).

\section{2...-Deducciones:}

1.- En las ventas de inmuebles sobre los que pesan censos o gravámenes análogos: el valor del gravamen, (R.S. de 21 de noviembre de 1889).

2. - En las ventas de inmuebles gravados con hipoteca: el monto de la deuda garantizada con hipoteca, siempre y cuando que el vendedor asuma expresamente la responsabilidad del pago de la misma, (R.S. de 20 de octubre de 1926).

3.-En las ventas de inmuebles en los que el arrendatario ha introducido mejoras: la parte del precio que corresponde a lo que el comprador ha pagado al arrendatario por las mejorers, (R.S. de 25 de febrero de 1910.

\section{VIII.-DETERMINACION DE LA DEUDA INDIVIDUAL DEL MPUESTO:}

\section{1.-Procedimiento:}

Aplicación de una tasa o porcentaje, según lo declarado por los interesados o el Notario o la estimación que haga a la Oficina Ácatadora, (arts. $1^{\circ}$ y $3^{\circ}$ de la ley 5004) (art. 8 Ley 15225)

\section{2.-Tasas vigentes:}

A.- En la transferencia de inmuebles, acciones o derechos sobre inmuebles y venta de naves nuevas y usadas, aportes de inmuebles a sociedades, adjudicaciones de bienes inmuebles por reducción de capital o disolución de sociedades: $6 \%$ (art. $1^{\circ}$ Ley 15225).

B. - En las transferencias a título oneroso de bienes muebles, acciones o derechos sobre éstos, vehículos y constitución de renta vitalicia y aporte muebles sociedades: $5 \%$

C.- En la transferencia de terrenos para uso de viviendas, que se paguen $\alpha$ plazos, con valor inferior $\propto$ S $\mid .100,000.00$, cuando el contrato privado se celebre antes de la promulgación de la Ley 15225 pagarán $5 \%$ sobre inmuebles ubicados en Lima y Callao, y en Provincias, siempre que el contrato se eleve a escritura pública dentro de los tres meses de vigencia Ley 15225 .

\section{2.-En los impuestos especiales:}

En la transferencia de concesiones petroliferas o de lotes no pagados totalmente en urbanizaciones del Estado: están afectos al 5\%, (art. 102 de la ley 11780; R.S. de 14 de diciembre de 1933 y R.S. de 10 de febrero de 1940). 


\section{3.-Reclamaciones Administrativas: A) De la Acotación}

1.-De la acotación practicada por el Departamento de transferencia de bienes a título oneroso, ante la Superintendencia Nacional de Contribuciones, (art. $1^{\circ}$ y $2^{\circ}$ de la R.M. 753-H de $1^{\circ}$ de setiembre de 1964).

2.-De las Resoluciones de la Superintendencia Nacional de Contribuciones, ante el Tribunal Fiscal, (art. $5^{\circ}$ del D...S. $N^{\circ} 5$ de 28 de febrero de 1964).

\section{B) De la Tasación:}

Los contribuyentes podrán contradecir las valorizaciones de la Superintendencia Nacional de Contribuciones en el caso de que esta efectúe tasaciones para comprobar valor declarado por interesados, dentro de los treinta días siguientes de notificados conforme procedimiento seguido por Impuesto Sucesiones (art. 9' Ley 15225)

\section{IX - PROCEDIMIENTOS DE RECAUDACION DEL IMPUESTO:}

\section{1 -Epoca de Pago}

Antes que la minuta sea elevada a escritura pública, artículo 20. Ley de Impuesto, art. 8 Ley 15225).

\section{2.-Lugar de Pago}

1.- En general:

a) Se efectuará antes de elevar la minuta a escritura pública. En la Caja de Depósitos y Consignaciones, Departamento de Recaudación, que previa liquidación otorgará la constancia de pago correspondiente para su entrega al Notario por los interesados (art. $2^{\circ}$ Ley Impuesto Registro, art. 8 Ley 15225).

b) La constancia de pago debe insertarse en las escrituras públicas y en las imperfectas $\mathrm{y}$ en los contratos legalizados por el Juez de Paz (art. 8० Ley 15225).

c) El pago de los impuestos y recargos con posterioridad a escritura pública o imperfecta convalidará las escrituras.

2.-En casos especiales:

El oficio del notario, cuando hay urgente necesidad de extender la escritura pública, en las horas que estén cerradas las oficinas de la Caja de Depósitos y Consignaciones, Departamento de Recaudación (art. 2\% de la Ley de Impuesto de Registro),

3.-Formalidades especiales anteriores al pago:

1.-En el caso de transferencia de concesiones petrolíferas: la entidad 
recaudadora no da el pase a la minuta si esta no tiene el visto bueno de la Dirección General de Petróleo (art. lo. D.S. de 17 de Junio de 1922).

2. - En la transferencia de concesiones de terrenos para irrigarlos la entidad recaudadora no aceptará el pago de la alcabala mientras la Dirección General de Águas no le manifiesta por escrito que está expedito el derecho de los que deseen celebrar la enajenación (art. 3o. de la R.S. de 7 de mayo de 1926).

3.-Cuando se trate de venta de inmuebles a plazos por documento privado, el impuesto se pagará al otorgarse la escritura pública correspondiente (art. 10 Ley 15225).

4.- Los impuestos que gravan transferencia de vehículos en documento privado se abonarán en certificados de pago de la Entidad Recaudadora que deberán ser adheridos al contrato bajo pena de nulidad.

5.-Prescripción:

1.-Término: a) 15 años, (inc. $2^{\circ}$ art. 1168 CC., RCSC 7739 de 26 de agosto de 1955).

No es aplicable a la alcabala de enajenaciones, la prescripción de tres años establecida por la ley No. 256 (R.S. de 11 de febrero de 1915) hasta promulgación art. 15 Ley 15225 de 23 Nov. 64 b) 10 años Ley 15225 de 23 de Noviembre de 1964.

2.-Competencia exclusiva: La Superintendencia Nacional de Contribuciones.

3.-Procedimiento: Recurso ante la Superintendencia Nacional de Contribuciones, que resuelve oyendo al Departamento de' Recaudación de la Caja de Depósitos y Consignaciones.

4.-Formas de Pago: a) Entrega directa por el contribuyente,

b) Entrega por el Notario que interviene en el acto.

\section{X. -MEDIDAS PARA CONTROLAR LA EVASION:}

1. - Medidas de contralor.-

10.-Medidas anteriores al pago del impuesto:

A.- Obligaciones de los Notarios:

a) Obligación de usar, para las minutas que se tramiten en su oficio una enumeración ininterrumpida, en relación con la que lleva la Caja de Depósitos y Consignaciones, Departamento de Recaudación, (art. lo. de la R.S. de 19 de Noviembre de 1942).

b) Obligación para el otorgamiento de toda escritura pública, de pasar previamente la minuta respectiva, original y copia, sólo para control cesantía negocios e industrias, por aportes, ventas fusión, traspaso, al Departamento de Bienes a título oneroso, de la Superintendencia Nacional de Contribuciones, (art. lo. de la Ley 5004).

c) Los Notarios no podrán elevar el contrato a escritura pública mientras no se acredite el pago del impuesto (art. 8\% Ley 15225).

d) Los Jueces de Paz no podrán sentar las actas y constancias seña- 
ladas en los artículas 203 y 205 de la Ley orgánica del Poder Judicial (Decreto Ley 14505) si previamente no se acredita el pago del impuesto (art. 80. Ley 15225).

e) Los Notarios deberán insertar en las escrituras públicas correspondientes, las constancias de pago del impuesto, bajo pena de nulidad de la escriturapú blica (crt. 8 Ley 15225).

1) Los Jueces de Faz en los casos de escrituras imperfectas y contratos legalizados mencionarán el valor del impuesto pagado y número de recibos y fechas respectivas bajo pena de nulidad (art. 8o. ley 15225).

g) Obligación en los casos de alteraciones o adiciones introducidas en las escrituras públicas, después de presentadas al Departamento de Transferencia de Bienes a Título Oneroso de la Superintendencia Nacional de Contribuciones $y$ antes de ser suscritas por los otorgantes, de hacer visar dichas alteraciones o adiciones por la entidad acotadora (R.S. de 31 de Diciembre de 1942).

h) Prohibición de dar trámite a minutas de contratos celebrados con el Gobieino en las que se estipula exención la Superintendencia Nacional de Contribuciones (art. 3o. de la R.S. de 30 de Octubre de 1942).

i) Los Notarios Públicos deberán remitir mensualmente a la Superintendencia Nacional de Contribuciones, copias de las minutas de contratos elevados a escritura pública el mes anterior, así como relación de contralos por documento privado legalizados.

j) Igual obligación para los Jueces de Paz.

B.-Obligaciones y facultades de las Entidades acoladora y recaudadora.

a.-.Obligación de expedir certificados de pago del impuesto o al declarar la exonercición del mismo, de numerar correlativamente las minutas que originen el pago o la exoneración, así como las copias respectivas. art. $1^{\circ}$ de la ley 5004).

b.-Prohibición de dar trámite a minutas de contratos celebrados con el Gobierno en los que se estipule exención de impuestos, sin enumerar los mismos o sin que haya informado previamente sobre la exención la Superintendencia Nacional de Contribuciones, (art. $3^{\circ}$ de la R.S. de 30 de octubre de 1942).

c.-Obligación de consignar en la minuta y en sus copias, en los casos de exoneración de impuesto su fundamento legal, (art. $3^{\circ}$ de la $\mathrm{R}$. S. de 19 de noviembre de 1942).

d.-Facultad de rechazar, para los efectos de la tributación el valor declarado en los contratos, cuando es evidentemente menor que el verdadero, (R.S. de 10 de junio de 1942).

e.-Obligación de rechazar las minutas que se le presenten que comprenda más renglones que los señalados en el papel sellado o que abcrquen cualquiera de los márgenes del mismo o cuyas copias sean ilegibles, (art. $4{ }^{\circ}$ del D.S. de 19 de noviembre de 1942).

f.-Prohibición de dar pase a minutas de venta de terrenos por mensualidades $\sin$ el visto bueno de la Inspección Fiscal del Rạmo، (R.S. de 21 de abril de 1926).

g) La Superintendencia Nacional de Contribuciones está autorizada 
para comprobar mediante tasación dentro de los 180 días, el valor de los bienes o derechos fijados en los contratos a la fecha que se celebraron, siguiendo las normas del Cuerpo Técnico de Tasaciones del Perú (art. 9o. Ley 15225).

h) El Ministerio de Hacienda inspeccionará las Notarías y Juzgados de Paz de la República, para comprobar si cumplieron requisitos establecidos por la Ley 15225. (art. 11\%).

i) El Estado podrá optar, en caso de expropicación de inmuebles, en pagar el precio que figura en la última transferencia de dominio del año anterior 0 el que resulte de la tasación de la ley 9125 (art. 3o. y 100.).

C. -Obligaciones de otras reparticiones públicas:

a.-De las reparticiones que intervengan a nombie del Gobiemo en la celebración de contratos en los que se conceda exinción de impuestos: obligación de remifir el respectivo proyecto de minuta a informe previo de la Superintendencia Nacional de Contribuciones, (art. $1^{\circ}$ del D.S. de 15 de setiembre de 1942; art. $2^{\circ}$ de la R.S. de 30 de octubre de 1942). En estos casos, la cláusula de exención deberá referirse expresamente al impuesto de alcabala, (art. $1^{\circ}$ de la R.S. de 30 de octubre de 1942).

b.-De la Superintendencia Nacional de Contribuciones: obligación de informar en los contratos celebrados con el Gobierno en los que se conceda exención de impuestos, (art. 10 del D. S. de 15 de setiembre de 1940).

\section{2.-Medidas posteriores al pago del impuesto:}

A. -Obligación de los Notarios: extender su Registro a los Visitadores de Notarías cuando éstos lo soliciten, (R.S. de 6 de febrero de 1902).

B.-Obligaciones de las entidades acotadoras y recaudadoras: remitir a la Superintendencia Nacional de Contribuciones y a la Caja de Depósitos y Consignaciones copias de las minutas que se le hayan presentado, junto con la liquidación del impuesto o con la exoneración del mismo, acompañada de su fundamento legal. Así mismo debe remitir relaciones periódicas de certificados de pago o de exoneración de impuestos, (art. $2^{\circ}$ y $3^{\circ} \mathrm{de}$ la R.S. de 19 de noviembre de 1942).

20.-Medidas represivas:

1.-Multas:

A. -Al contribuyente:

a) Cuatro veces el valor del impuesto, en los casos de omisión de pago del mismo (R.S. de 8 de Diciembre de 1905).

b) Recargo del $100 \%$ sobre la diferencia del impuesto resultante en caso de que la tasación fiscal apareciera que el valor del bien es mayor en $40 \%$ del válor que aparece en el contrato (art. 9\% Ley 15225).

B. -A los Notarios:

a) Diez veces el valor del impuesto en los casos en que omitan pa- 
sar a la Superintendencia Nacional de Contribuciones, Departamento de Transmisión de Bienes a Título Oneroso, la minuta de un acto o contrato afecto a impuesto o el monto del mismo, en los casos en que están autorizados para percibirlos (art. 16 Ley de Registros, y art. 3o. Ley 4881). En el valor de las multas por galta de impuesto, está incluído el valor del mismo cuyo pago se omitió (R.S. de 16 de Agosto de 1906).

b) Los Notarios y Jueces de Paz que no cumplan con las obligaciones que imponen art. $8^{\circ}$ Ley 15225 (ver medidas preventivas c, d, e, f, i) serán sancionados con $S_{\mid}$. 5,000.00 de multa según la falta $y$ en caso de reincidencia. suspensión en sus funciones hasta por dos años.

c) Los Notarios y Jueces de Paz que no cumplan con remitir a la Superintendencia de Contribuciones mensualmente, copia de las minutas y relación de contratos, se harán acredores a la aplicación de una multa hasta por $\mathrm{S} \mid .20,000.00$ (art. 13ㅇ Ley 15225).

\section{2.-Nulidad:}

a) De las escrituras públicas que se celebran sin haber abonado el impuesto de alcabala cuando esta deba pagarse (art. $3^{\circ}$ Ley 4881).

b) De las cláusulas de exención de impuesto en los contratos celebrados con el Gobierno, que no hayan sido visadas previamente por la Superintendencia Nacional de Contribuciones (art. $2^{\circ}$ D.S. de 15 de Setiembre de 1942).

c) De escrituras públicas en que no se inserte la constancia de pago del impuesto (cart. $8^{\circ}$ Ley 15225).

d) Igual nulidad para escrituras imperfectas y contratos legalizados ante Jueces de Paz si no se menciona valor de impuestos pagados (art. $8^{\circ}$ Ley 15225).

e) Los documentos privados de transferencia de vehículos sino que se adhiere certificado de pago impuesto (art. 12 Ley 15225).

\section{9._Otra modida ropresiva:}

1) A los Notarios que, con evidente mala fe, autoricen escrituras sujetas a impuesto, sin que se haya abonado éste: destitución del cargo e inhabilitación para desempeñarlo, (art. $16^{\circ}$ de la Ley de Impuesto de Regis. tro). 2) Los Notarios y Jueces de Paz que reincidan en no cumplir oblig. de inscrita Const. pag. impuesto o dar realicen de ella será suspendido hasta por 2 años.

\section{0.-Medidas Conexas:}

1.-Medida para estimular el celo de los particulares:

Prima a la delación por falta de pago de impuesto, que se otorgará en la forma siguiente:

- A. - La mitad de lo recaudado en los casos en que haya aplicación de multa, (R.S. de 18 de febrero de 1903).

B.-La tercera parte de lo recaudado, en los casos que no haya aplicación de multa, (R.S. de 5 de junio de 1914). 
2. -Medida para estimular el celo de los funcionarios de la Ádministración pública:

Atribución de las multas al Fondo de Empleados de la Caja de Depósitos y Consignaciones, Departamento de Recaudación.

\section{XI.-GARANTIAS DEI. CONTRIBUYENTE:}

1.- Obligación de la entidad acotadora, si encuentra conforme la indicación del Notorio sobre el monto del impuesto, de poner pase a la minuta el mismo día en que la ha recibido, previo, pago del impuesto, (art. 2 de la Ley 5004).

2.-Obligación de la entidad acotadora, si no está conforme con lo indicado por el Notario sobre el monto del impuesto, de indicar el valor que, a su juicio, debe pagarse y de devolver la minuta, con el recibo que acredit el pago del impuesto, dentro de las 24 horas de la recepción de la misma, (ant. 3o de la ley 5004).

3.- Obligación de la entidad recaudadora de conservar en depósitoel exceso pagado sobre la estimación del Notario, durante el tiempo en que el interesado pueda reclamar de la acotación $y$ estando pendiente dicha. reclamación, (art. $4^{\circ}$ y $8^{\circ}$ de la ley 5004).

4.-Prohibición a la entidad acotadora, al dar el pase a la minuta respectiva, de negarlo por deuda de cualquier otro impuesto que no sea el de alcabala, (art. 99 de la ley 5004; R.S. de 26 de enero de 1940).

5.-Prohibición a la entidad acotadora de imponer recargo alguno. al cobrar impuesto sobre escrituras privadas 0 autorizadas por los Jueces de Paz, extendida en lugares donde no haya empleado de la entidad acotadora y recaudadora, cualquiera que sea el tiempo en que los interesados. se presenten a pagarlo o se les cobre, (R.S. de 16 de agosto de 1906).

6.-Obligación de inscribir los contratos de compra-venta privados, al contado o a plazos, de promesa de venta, inclusive minutas en el Registro de la Superintendencia Nacional de Contribuciones (art. 20 ley 15225).

\section{XII.-LA RECLAMACION ANTE EL PODER JUDICIAL:}

1.-Causas de reclamación ante el Poder Judicial:

1.-Aplicación ilegal del impuesto.

2.-Cobranza ilegal del impuesto.

2:-Requisito indispensable para reclamar ante el Poder Judicial: pa-

go del impuesto de que se reclama. (ver. av. 10 Ley P F 965 31-XII-64.

3:--Juez Competente: el de Primera Instancia de Lima.

4\%.-Procedimiento: el del juicio de menor cuantía. 
$5^{\circ}$.-Los Jueces remitirán Control Rep. fallos livs ent., dos o tres en que Estado sea demandante o demandado; y de ser contrario a denelas Estado. Contralor dentro del año mandará investigar y si hay negligencia denunciar a funcion resp. ante M. F. (art. 104 Ley Pres. E5. No 13270 $3 / \mathrm{XII} / 64$.

6.-Devolución del pago indebido: Devuelve la Caja de Depósitos y Consignaciones, Departamento de Recaudación; con cargo a la respectiva partida del Título de Ingresos del Presupuesto Funcional, mediante Resolu-. ciones en cada caso, del Superintendente Nacional de Contribuciones, cuando la cuantía devuelta no exceda de S|. 300,000.00 y del Ministerio de Hacienda y Comercio. cuando supere dicha cuantía. 
MINISTERIO DE HACIENDA Y COMERCIO

SUPERINTENOENCIA DE CONTRIBUCIONES

LIQUIDACION DE LOS IMPUESTOS A LA TRASMISION DE BIENES A TITULO ONEROSO

1.-DATOS SOBRE EL ACTO O CONTRATO

Minuta No

Contratantes:

Nolaria:

Naturaleza del acto o contrato:

\section{2.-LIQLHDACION DE LOS MMPLFSTOS}

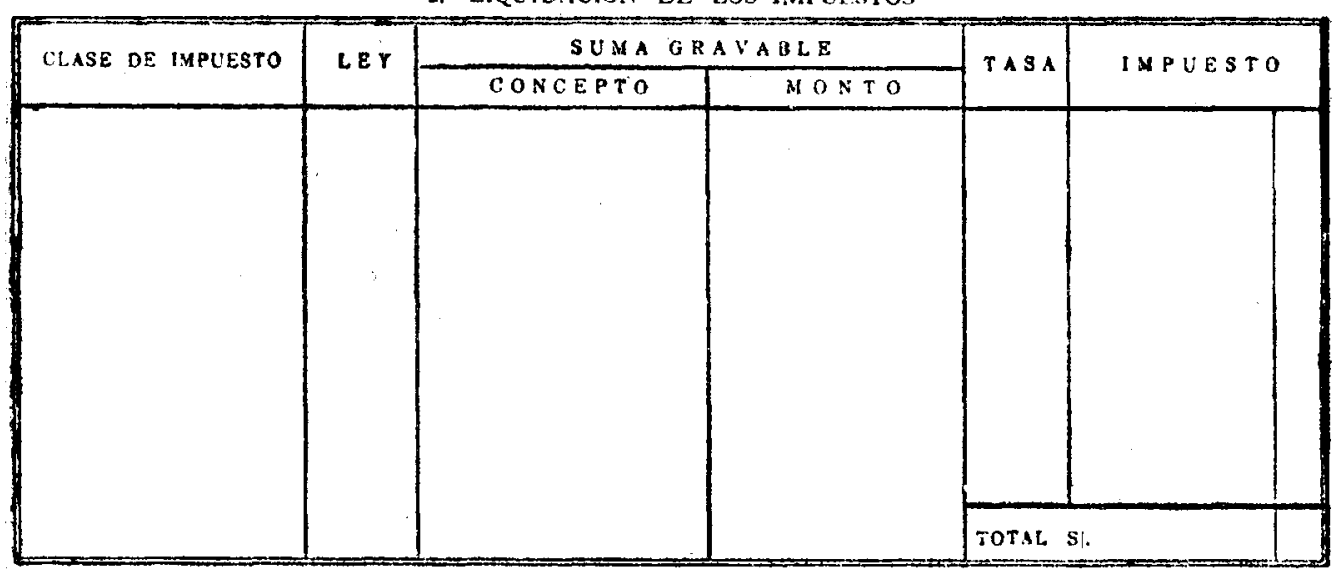

3.-OBLIGADO AL PAGO

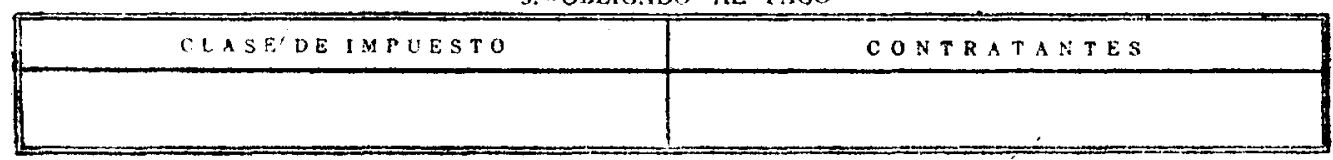

4.-LIQUIDACION DF laS MULTAS

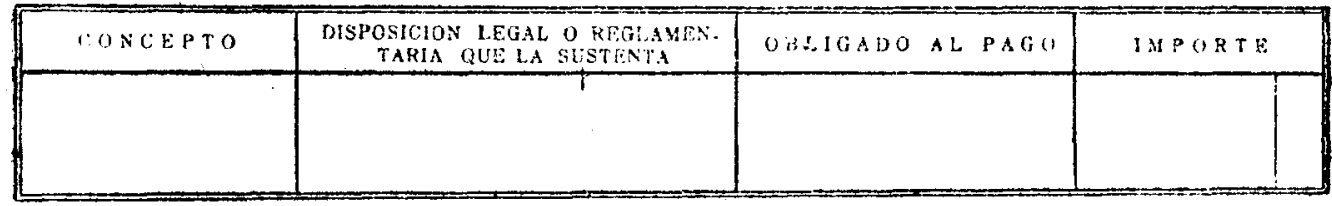

5.- EXONERACIONES

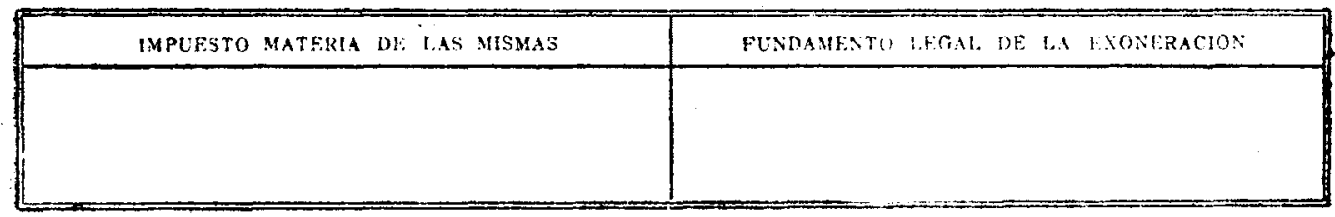

\begin{tabular}{|l|l|}
\hline Opli. de Transferencias a Titulo Oneroso \\
\hline Liquidador & Jefe del Departamento \\
\hline
\end{tabular}

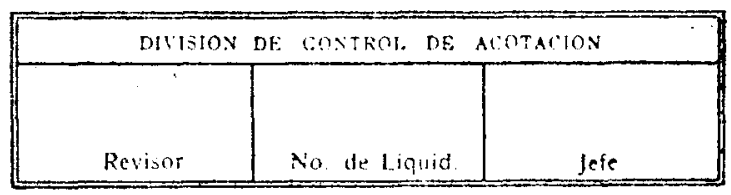

Emitame tos recihos coraspondiertes

L.ima, 